\title{
EL JUSTICIA DE LAS MONTAÑAS DE ARAGÓN (1585-1672): LA INSTITUCIÓN Y SUS OFICIALES ${ }^{1}$
}

\author{
JOSÉ IGNACIO GÓMEZ ZORRAQUINO \\ Universidad de Zaragoza
}

A María Rivas Palá, archivera, excelente profesional...

Este estudio pretende profundizar en una magistratura aragonesa «controlada» por la realeza, que tuvo vida durante aproximadamente un siglo (1585-1672), y que es un buen botón de muestra de la serie de parcelas de poder dominadas total o parcialmente por la Monarquía en Aragón en los siglos XVI y XVII (el justicia de Aragón, el virrey, los oficiales de la Real Audiencia, el gobernador, el baile general, los bailes locales de las poblaciones de realengo, algunos zalmedinas, los merinos,...). Lógicamente, el control monárquico no era gratuito, ya que detrás de dichos cargos estaban en juego una serie de intereses políticos, socioeconómicos y culturales. Estudiar estas parcelas de poder real se hace especialmente imprescindible para entender la historia de Aragón durante el periodo en que reinó la dinastía de los Austrias.

No debemos perder de vista que la administración real convivía con la regnícola y con la local, dándose la circunstancia de que esta última sufría un importante intervencionismo monárquico - a través de las insaculaciones, los ascensos en los oficios, el nombramiento puntual de los justicias locales ${ }^{2}, \ldots-$. Aunque en menor medida, la admi-

1. Este trabajo forma parte de las investigaciones que lleva a cabo el Grupo Consolidado de Investigación Blancas, reconocido por el Gobierno de Aragón.

2. Sobre los diversos ámbitos de relación -intervencionista o no- entre el poder real y los concejos de la Corona de Aragón se hace imprescindible el trabajo de síntesis de David Bernabé Gil. BERNABÉ GIL, D. «Ámbitos de relación entre el poder real y los municipios de la Corona de Aragón durante la época foral moderna», Estudis, no 32 (2006), pp. 49-72. No podemos olvidar el puntual trabajo de TORRAS I RIBÉ, J.M. «La desnaturalización del procedimiento insaculatorio en los municipios aragoneses bajo los Austrias», Studia Historica. Historia Moderna, 15 (1996), pp. 243-258. Este estudio también está publicado en ActasXV Congreso de Historia de la Corona de Aragón, tomo I, vol 2ª Zaragoza, 1996, 
nistración regnícola tampoco escapaba de la influencia de la realeza. Esto significa que hay que revisar profundamente la «foralidad» aragonesa, el intervencionismo regio, los «apoyos» con que contó la Monarquía y el interés que mostraban los aragoneses por estar cerca de quien controlaba verdaderamente el poder. Todo ello sin olvidar que la administración de la Monarquía «se efectuaba más por relaciones personales que por razones institucionalizadas y, por consiguiente, que la elección de sus servidores se llevaba a cabo más por razones clientelares (de fidelidad) de los grandes patrones que se hallaban cerca del rey, que por criterios de suficiencia y aptitud del aspirante al cargo» ${ }^{3}$. Además, también debemos recordar que la venta de hábitos de las órdenes, señoríos, oficios militares, magistraturas,... fue una constante a lo largo de la Edad Moderna. Parecía «como si la monarquía se hubiera convertido en una inmensa almoneda $[\ldots]\rangle^{4}$.

Ante esta serie de circunstancias es lógico pensar que la administración real en Aragón era atractiva para los aragoneses porque ofrecía un amplio abanico de cargos con una remuneración nada despreciable - con bastantes posibilidades de ampliarla con «complementos» por participar en las comisiones de insaculación,...-, dándose además la circunstancia de que entrar en dicho engranaje podía catapultar a sus titulares a ocupar puestos más relevantes dentro del amplio entramado administrativo que dominaba la Monarquía allende las fronteras aragonesas ${ }^{5}$. Estamos seguros de que las futuras investigaciones que profundicen en este campo -bastante «virgen»-depararán importantes sorpresas. No olvidemos que -aunque en un contexto diferente- el cronista de Aragón Bartolomé Leonardo de Argensola ya denunció en los años veinte del siglo XVII que el ascenso en la carrera política en Aragón se lograba -en tiempos de Felipe II- no por méritos sino por los servicios prestados a la Monarquía, que estaba abierta a la compra de voluntades y a la concesión de prebendas ${ }^{6}$.

pp. 399-414. La interpretación de Torras tuvo respuesta en el trabajo de JARQUE MARTínEZ, E. y SALAS AUSÉNS, J.A. «Monarquía, comisarios insaculadores y oligarquías municipales en el Aragón de la segunda mitad del siglo XVII», Revista de Historia Moderna. Anales de la Universidad de Alicante, $\mathrm{n}^{\mathrm{o}} 19$ (2001), pp. 239-268.

3. Recordatorio de José Martínez Millán, quien ha hablado del tema en varias publicaciones. MARTíNEZ MilláN, J. «Las investigaciones sobre patronazgo y clientelismo en la administración de la Monarquía Hispana durante la Edad Moderna», Studia Historica. Historia Moderna, 15 (1996), p. 94.

4. Castellano, J.L. «La movilidad social. Y lo contrario», Gómez GonZÁlez, I. y LóPEZ-GuAdALUPE MuÑoz, M.L. (Eds.), La movilidad social en la España del Antiguo Régimen, Granada, Comares, 2007, p. 10.

5. Estamos plenamente convencidos de que los oficiales que participaban en las comisiones de insaculación eran nombrados por el monarca para «recompensarles por sus servicios políticos o incluso pecuniarios» -como apuntan E. Jarque y J.A. Salas en Monarquía..., op.cit., p. 247-, lo que no descarta que los titulares pudiesen prestar en ese momento unos servicios políticos parecidos a los ejecutados anteriormente. Debemos tener en cuenta que tanto los «servicios» como sus respectivos «pagos» podían jugar con actuaciones «pasadas», «presentes» o «futuras».

6. ColÁs LATORRE, G. «Bartolomé Leonardo de Argensola y la rebelión aragonesa de 1591», en LEONARDO De Argensola, B. Alteraciones populares de Zaragoza. Año 1591, Zaragoza, Institución «Fernando el Católico», 1995, pp. 71-72. 
Solamente teniendo en cuenta este complejo marco de intereses podremos entender mejor la institución y los oficiales que nos proponemos estudiar. Fue en las Cortes de Monzón y Binéfar de 1585 cuando se creó el cargo de justicia de Jaca y de las montañas de Aragón ${ }^{7}$, magistrado -natural y domiciliado en Aragón- de nombraminto real, con carácter vitalicio y hereditario, que sustituía a los justicias ordinarios en las universidades de realengo - y no en los lugares de señorío- de una amplia zona pirenaica de Aragón. La función de dicho magistrado era «exercitar jurisdicion criminal en los crimines y delictos infrascriptos» y siguientes: "contra los Vandoleros de seguida, y en los crimines de Hurtos, Assassinamientos, Homicidios, Raptos y de saltear caminos y no en otros algunos... ${ }^{8}$. Podía intervenir -dentro de dicha área territorial- en los procesos criminales iniciados con anterioridad por los justicias de los diversos concejos. También tenía poder para ejecutar las sentencias judiciales que ya habían sido dictadas por los citados justicias. Los procesos debían respetar los fueros y leyes de Aragón. El justicia de las montañas debía consultar a la Real Audiencia de Aragón las sentencias definitivas y cualquier otra obligación que habitualmente tenían los jueces ordinarios. Finalmente, se establecía la posibilidad de que los procesados pudiesen apelar a la Real Audiencia9.

En las Cortes de 1626 de Barbastro y Calatayud se prorrogó el oficio mediante un nuevo fuero hasta las siguientes Cortes, aunque puntualizando que el que ejerciese el cargo no nombrase al justicia de Jaca «ni tenga, ni exercite jurisdicion alguna en dicha Ciudad, ni en sus terminos» ${ }^{10}$. Posteriormente, en las Cortes de 1645-1646 de Zaragoza se estableció la prórroga del oficio durante la vida del titular -en ese momento era don Jerónimo Pérez de Sayas- y de su nieto -llamado José Pérez de Sayas- ${ }^{11}$. A la muerte de este último el oficio debía extinguirse. La fatalidad quiso que esto ocurriese en 1672, cuando se produjo, con tan solo treinta y siete años, el óbito de don José Pérez de Sayas -como analizaremos más adelante-, lo que suponía que la citada magistratura había tenido una vida aproximada de un siglo.

Teóricamente, esta magistratura vio la luz como un intento de dar respuesta al estado de alteración que se vivía en Aragón como consecuencia del bandolerismo, de especial incidencia en la zona pirenaica ${ }^{12}$. Esta intervención contra la delincuen-

7. A partir de 1626 se le conoció como justicia de las montañas de Aragón.

8. Savall, P. y PenÉn, S. Fueros, observancias y actos de Corte del reino de Aragón (ed. facs. con estudio preliminar de Jesús Delgado Echeverría), Zaragoza, El Justicia de Aragón-IberCaja, 1991, tomo I, p. 421. LeOnardo De Argensola, L. Información de los sucesos del Reino de Aragón en los años de 1590, 1591..., Madrid, Imprenta Real, 1808 (edición facsímil bajo los auspicios de El Justicia de Aragón-Rolde de Estudios Aragoneses, con introducción de Xavier Gil Pujol), Zaragoza, 1991, p. 26.

9. SaVAll, P. y PenÉn, S. Fueros..., op.cit., tomo I, pp. 421-422.

10. Savall, P. y PenÉn, S. Fueros..., op.cit., tomo I, pp. 454-455.

11. SaVAll, P. y PenÉn, S. Fueros..., op.cit., tomo I, p. 493.

12. COLÁs, G. y SALAS, J.A. Aragón en el siglo XVI: alteraciones sociales y conflictos políticos, Zaragoza, Departamento de Historia Moderna, 1982, pp. 173 y 366. El fenómeno del bandolerismo es analizado en las páginas 153-411. 
cia trataba de mantener el orden -función que los fueros aragoneses reservaban a la Monarquía- con unas reglas que podían entrar en confrontación con los propios fueros y con las normativas locales. Todo esto sin olvidar en ningún momento que los lugares de señorío - donde no tenía competencias dicho justicia- podían servir de verdaderos «paraísos» de delincuentes, lo que restaba importancia al oficio creado para ejercer una puntual jurisdicción criminal. En estas circunstancias era lógico que el cargo despertase en sus inicios pocas simpatías entre los montañeses. Los concejos estaban expectantes porque podían ver recortadas sus jurisdicciones y la pequeña nobleza (los Abarca, Latrás, Bardají, Mur, Aragüés,...) -que utilizaba los actos de bandolerismo y contrabando para mejorar sus exiguos ingresos- porque veía peligrar una fuente de sus ingresos. La realidad demostró, en los primeros años de funcionamiento, que el cargo era temible para los intereses de la pequeña nobleza altoaragonesa, ya que habían sido apresados algunos de sus miembros. Ante esta situación, la pequeña nobleza en vez de esforzarse por conseguir la desaparición del cargo pasó a intentar controlarlo -como luego veremos- por temor a ser detenidos y por el poder que tenía, en nombre del rey, de ordenar ahorcamientos, condenar a galeras, $\ldots{ }^{13}$.

El sustento de los justicias de las montañas estaba asegurado con los 12.000 sueldos jaqueses que cobraban anualmente, pagados por cuatrimestre de las Generalidades de Aragón ${ }^{14}$. También retribuía el General a los veinte soldados que tenía asignados dicha magistratura, quienes tenían una paga mensual de «cuatro ducados de a once reales» cada uno y el cabo de la escuadra cobraba otros tres ducados más ${ }^{15}$. Sin embargo, cuando la institución empezó a andar, el Consejo de Aragón reconoció que el salario del justicia era corto. El primer justicia don Jerónimo [Fernández] de Heredia no tardó en expresar su malestar -cuando informó que había vendido parte de su hacienda para cumplir con el cargo- y solicitó al rey que le entregara a perpetuidad los alcaidados de Ruesta y Candaljub (Candanchú), que valían 1.250 reales, a los que había que sumar otros 400 derivados del arrendamiento de los derechos del castillo de Candanchú ${ }^{16}$. Don Jerónimo logró ambos alcaidados. Desconocemos las particularidades del alcaidado de Ruesta. Por el contrario, tenemos noticias del de Candanchú ${ }^{17}$, ya que sabemos

13. Desportes Bielsa, P. «El Justicia de las Montañas», Serrablo, n ${ }^{\circ} 108$ (1998), p. 23. Entre 1585 y 1594 fueron detenidos Miguel de Latrás, señor de San Vicente; Barbalisa; Felipe de Bardají, señor de Villanova; Bernard de Lana, lacayo de Lupercio Latrás; Marco de Allué, que había participado en las alteraciones de Zaragoza ayudando al justicia de Aragón; y seis bandoleros.

14. SAVAll, P. y PenÉn, S. Fueros... op.cit. tomo I, p. 422. Dos ejemplos de ello, en A(rchivo) H(istórico de) P(rotocolos de) Z(aragoza). Juan Escartín, 1591, ff. 237v-238r. A(rchivo) H(istórico) Pr(ovincial de) H(uesca). Pedro Santapau, 1629, 1-IX, ff. 644v-645r.

15. Savall, P. y Penén, S. Fueros..., op.cit., tomo I, p. 422.

16. DesPortes BielsA, P. «El Justicia de las Montañas», op.cit., pp. 23-24, nota 10.

17. El castillo de Candanchú era a mediados del siglo XVI una «posesión del monarca, el cual lo cedía a un vasallo que lo regía a cambio de un salario y unos beneficios, con la obligación de devolverlo en el momento que el monarca lo considerara oportuno». DESPORTES BIELSA, P. «Actividad fronteriza en el Pirineo aragonés: el castillo de Candanchú a mediados del siglo XVI», Serrablo, n 104 (1997), pp. 29-30. 
que un sucesor de don Jerónimo controló los ingresos inherentes al cargo de alcaide de dicho castillo -amén de que también cumplía la mayoría de los requisitos personales que se habían exigido hasta ese momento a los alcaides $-{ }^{18}$, consistentes en un salario anual y en los ingresos que reportaba el derecho de la «rota» ${ }^{19}$ (era un impuesto especial que gravaba a toda persona -con mercancías o sin ellas-que pasaba por el puerto de Somport tras la eliminación de la nieve que impedía el tránsito de personas y animales durante el periodo invernal $)^{20}$.

El justicia de las montañas de Aragón -cuyo distintivo o insignia era un bastón o vara, a imagen y semejanza de la que llevaban otros justicias de los concejos aragoneses $^{21}$ - se debía ayudar de varios lugartenientes - uno como mínimo en cada valle que gobernaba $^{22}$ - y de un jurista como asesor ${ }^{23}$. Sabemos que el justicia de las montañas lo era de Jaca, Berdún, Bielsa, Biescas, los valles de Basa y Serrablo, el valle de Tena, el valle de Aragüés del Puerto, San Esteban de Litera, Boltaña, Adahuesca, el valle de Aísa, el valle de Hecho, Salvatierra, Gistau... También era alcaide de los castillos

18. Debían ser hidalgos, «personas recelosas y cuidadoras», de la localidad de Canfranc, personas acaudaladas, que estuviesen bien «emparentados» para reunir gente contra cualquier invasión bearnesa,... DesPortes Bielsa, P. «Actividad fronteriza...», op.cit., pp. 30-31 y Serrablo, no 105 (1997), pp. 21-24.

19. A mediados del siglo XVI el salario anual rondaba los 56 escudos y los ingresos por el derecho de la «rota» podían llegar a los 100 ducados anuales. DESPORTES BIELSA, P. «Actividad fronteriza...», $\mathrm{n}^{\circ} 105$ (1997), op.cit. p. 21.

20. Tenemos constancia documental y bibliográfica de que el derecho de «rota»-hermanado al derecho de «porta», con filiación con el arreglo de los caminos- fue arrendado por el caballero don Jerónimo Pérez de Sayas, justicia de las montañas de Aragón. Así, el 19 de noviembre de 1656 Pérez de Sayas rescindió el contrato vigente en ese momento por impago del arrendatario y acordó uno nuevo con Jaime de Fonz, vecino de Canfranc, por un periodo de 10 años y un precio de 200 sueldos jaqueses anuales. AHPrH. Vicencio Santapau, 1656, 19-XI, ff. 1050r-1052r. ÁlvAREZ, M. «Apuntes históricos sobre el municipio de Canfranc», Pirineos, n' ${ }^{\circ} 23$ (1952), pp. 62-66. BOYA Y SAURA. L. El archivo de Canfranc. Inventario y documentos, Huesca, Imprenta Martínez, 1972, pp. 15-19.

21. SAVAll, P. y PEnÉN, S. Fueros..., op.cit., tomo I, p. 422.

22. Tenemos noticias de los lugartenientes del valle de Tena gracias al trabajo de GómEZ DE VALENZUELA, M. La vida en el valle de Tena en el siglo XVII, Huesca-Sallent de Gállego, Instituto de Estudios Altoaragoneses-Ayuntamiento de Sallent de Gállego, 2005, p. 58. También tenemos constancia del nombramiento de lugarteniente que se hizo el 5 de abril de 1612 en el valle de Gistau. AHPrH. Pedro Santapau, 1612, 5-IV, ff. 221r-221v.

23. Sabemos que en 1620 el asesor era el oscense doctor micer Juan de Olcina. En 1655 dicho cargo era ocupado por el también oscense doctor José Esporrín. GómEZ DE VALENZUELA, M. Estatutos y Actos Municipales de Jaca y sus montañas (1417-1698), Zaragoza, Institución «Fernando el Católico», 2000, p. 433. B(iblioteca) N(acional de) M(adrid). Ms. 8382, ff. 188v-189v. PÉREZ COLlados, J.M. Una aproximación histórica al concepto jurídico de nacionalidad. La integración del Reino de Aragón en la monarquía hispánica, Zaragoza, Institución «Fernando el Católico», 1993, p. 258, nota 711. Por otra parte, el 20 de mayo de 1645 el ciudadano barbastrense y jurista micer Domingo Caverni fue nombrado asesor del justicia de las montañas en la zona de Barbastro -el nombramiento del virrey don Bernardino Fernández de Velasco llevaba fecha de 24 de febrero de 1645-, sustituyendo al doctor José Andrés de Buesa. AHPrH. Vicencio Santapau, 1645, 20-V, ff. 334v y ss. 
de Candanchú y Ruesta ${ }^{24}$. Esto significa que dicho justicia tenía jurisdicción en una amplia extensión territorial de la zona pirenaica y prepirenaica que llegaba hasta muy cerca de Huesca, ciudad que quedaba fuera de su ámbito de actuación, al igual que la ciudad de Barbastro y las villas de Sos, Uncastillo, Sádaba, Ejea de los Caballeros, Tauste y Tamarite de Litera. Tal como hemos adelantado, tampoco tenía jurisdicción en ninguno de los lugares de señorío que había dentro de los límites del distrito que acabamos de señalar ${ }^{25}$.

De acuerdo con las funciones que tenía este oficio, debemos preguntarnos por la ubicación de la sede donde ejercía el cometido de juzgar a los detenidos. Todo apunta a que las causas se tramitaban en las poblaciones donde se iniciaban los procesos. En la misma línea de actuación, los individuos detenidos y encarcelados eran retenidos en las cárceles públicas de las localidades donde eran prendidos ${ }^{26}$. Esto no descarta que la sede oficial de la magistratura pudiese estar en la ciudad de Huesca. Una referencia documental indirecta nos sitúa la casa del justicia de las montañas de Aragón enfrente de una vivienda que llevó al matrimonio don Diego Vincencio de Vidania ${ }^{27}$. Esta información se puede completar con el dato de que en 1664 dos soldados al servicio de esta magistratura residían en Huesca cuando decidieron testar ${ }^{28}$. Además, el justicia don Jerónimo Pérez de Sayas y sus sucesores aparecen citados en varios documentos privados como domiciliados en la ciudad de Huesca ${ }^{29}$.

Otro asunto que tampoco está resuelto es el de las personas que ocuparon el citado cargo real. El primer justicia de Jaca y de las montañas de Aragón fue don Jerónimo Fernández de Heredia, quien fue nombrado por privilegio real de 3 de agosto de $1586^{30}$ y estuvo en el oficio hasta que el 30 de agosto de 1601 juró el cargo de gobernador de

24. Desconocemos por qué se dejaba la opción de ejercer el oficio de justicia o alcaide en los valles pirenaicos citados. También se abría la posibilidad de desempeñar el oficio de justicia o baile en la villa de Adahuesca. A(rchivo) H(istórico) Pr(ovincial de) Z(aragoza). Fondo Argillo, caja 2187/1-15.

25. SaVAll, P. y PenÉn, S. Fueros..., op.cit., tomo I, p. 423.

26. SAVAll, P. y PenÉn, S. Fueros..., op.cit., tomo I, p. 422.

27. AHPZ. José Sánchez del Castellar, 1672, 16-I, ff. 197v-220v.

28. AHPrH. Pedro Silverio Fenés de Ruesta, 1664, 2-IV, ff. 260v-262r; 1664, 16-IV, ff. 263r-265r. El 19 de agosto de 1668 el portero real de dicha magistratura era Jerónimo Rivares. AHPrH, Papeles de justicia, caja 1198/21, f. 1v.

29. El 9 de septiembre de 1618 don Jerónimo dio un poder a don Toribio Remírez de Ateca, caballero de Calatayud, para que este último pudiese arrendar y entregar contracartas en Calatayud. AHPrZ. Fondo Argillo, caja 2147/43 (leg. 42/43).

30. Una de sus actuaciones fue la sentencia arbitral que dictó el 11 de junio de 1589, donde ponía orden a las diferencias entre las cofradías de Santiago y San Pedro de Sallent de Gállego. También fijó sus puestos y conducta en el concejo de dicha población. GómEz De VALENZUELA, M. Diplomatario tensino (13151700), Zaragoza, Real Sociedad Económica Aragonesa de Amigos del País, 2006, pp. 335 y 339-344. 
Aragón $^{31}$-que logró por privilegio real dado en Valladolid el 20 de agosto de $1601^{32}$-. Mientras esto ocurría, don Jerónimo Fernández de Heredia y micer Juan Miguel de Olcina y Arbués fueron comisarios reales para llevar a cabo en 1594 las ordinaciones de la villa de Loarre y sus aldeas ${ }^{33}$. Antes del nombramiento como gobernador, Su Majestad, en una orden dada en Madrid el 30 de octubre de 1599, había establecido que el sucesor de don Jerónimo Fernández de Heredia como justicia de Jaca y de las montañas de Aragón fuese su hijo Juan, quien también debía recibir los alcaidados que tenía su padre ${ }^{34}$.

No tuvo efecto la citada provisión porque el nuevo justicia fue don Jerónimo Pérez de Sayas, yerno de don Jerónimo Fernández de Heredia, quien fue nombrado por el rey justicia de la villa de Berdún el 26 de julio de $1602^{35}$. Parece ser que Sayas tuvo

31. Como gobernador siguió encargándose de la persecución de los delincuentes, además de ejercer otras funciones de menor calado. Sustituía a don Juan de Gurrea, quien ocupó el cargo desde 1554 hasta 1590 -con su coadjutor Alonso Celdrán desde agosto de 1587- y a don Ramón Cerdán -quien desempeñó el oficio desde 1590 hasta 1601, cuando acaeció su muerte-. COLÁS, G. y SALAS, J.A., Aragón en el siglo XVI..., op.cit., pp. 370 y 396.

32. GASCÓN PÉREZ, J. La rebelión aragonesa de 1591, Tesis Doctoral, Universidad de Zaragoza, 2000, t. II, pp. 1302-1304 [Hay ed. electrón. Zaragoza, Universidad de Zaragoza, 2001].

La muerte de don Jerónimo -que en ocasiones es citado como don Jerónimo de Heredia- propició que en San Lorenzo de El Escorial el 10 de abril de 1608 el rey nombrase a su hijo el caballero mesnadero don Juan [Fernández] de Heredia como regente del oficio de gobernador de Aragón. El 16 de junio de 1608 se dio licencia a don Juan para que hiciese «dejación» del hábito de la orden de caballería de Santiago -había recibido el hábito en la Catedral de Huesca el 19 de octubre de 1593-, conforme a los fueros aragoneses, mientras durase su cargo de gobernador de Aragón. Años más tarde, «teniendo en consideración los servicios prestados» por don Juan Fernández de Heredia, el rey hizo merced el 4 de febrero de 1627 de que el sucesor del cargo de regente del oficio de la General Gobernación de Aragón fuese su hijo el caballero mesnadero del hábito de Santiago don Pedro Pablo Fernández de Heredia y Zapata, quien se convirtió en el VI conde de Aranda y por ello aparece también citado en la documentación como Pedro Pablo Ximénez de Urrea Fernández de Heredia y Zapata. Éste, cumpliendo con la normativa, tuvo que dejar temporalmente el hábito de Santiago para ser gobernador y cuando accedió al título de conde de Aranda -tras la muerte sin sucesión en 1654 del V conde de Aranda don Antonio Ximénez de Urrea y por sentencia de la Real Audiencia de Aragón de 20 de noviembre de 1656- tuvo que renunciar al cargo de gobernador. La dimisión fue firmada en Madrid el 21 de marzo de 1661. El nuevo gobernador en 1661-1662 fue don Francisco Luis de Gurrea. En junio de 1662 el rey debió de nombrar a Don Pedro Jerónimo de Urriés como nuevo regente de la Gobernación en Aragón, quien debió de permanecer en el cargo hasta que murió en 1696. LALINDE ABADíA, J. La Gobernación General en la Corona de Aragón, Zaragoza, Institución «Fernando el Católico», 1963, pp. 271-272, 277-278 y 534535. Moreno Meyerhoff, P. «Genealogía y patrtimonio de la Casa de Aranda», El Conde de Aranda, Zaragoza, Gobierno de Aragón-Diputación de Zaragoza-iberCaja, 1998, p. 44.

33. Estas ordinaciones fueron impresas en Zaragoza en 1681 por los herederos de Pedro Lanaja Lamarca. Gómez URIEL, M. Bibliotecas antigua y nueva de escritores aragoneses de Latassa, aumentas y refundidas en forma de diccionario bibliográfico-biográfico, Zaragoza, Calisto Ariño, 1884-1886, tomo II, p. 423.

34. AHPrZ. Fondo Argillo, caja 2187/37 (leg. 79/37).

35. En esa misma fecha fue nombrado justicia o alcaide de los valles de Basa y Serrablo, del valle de Ansó, del valle de Gistau y justicia o baile de Adahuesca. AHPrZ. Fondo Argillo, caja 2187/33-36 (leg. 79/3336); caja 2108/8 (leg. 8/8). 
como adjunto a su cuñado don Juan Fernández de Heredia, hasta que en los primeros meses de 1607 el Consejo de Aragón entendió que don Juan podía sustituir a Sayas ${ }^{36}$. Poco tiempo estuvo don Juan Fernández de Heredia en el cargo de justicia de Jaca y de las montañas de Aragón, ya que, como hemos anticipado en una nota, fue nombrado gobernador de Aragón por provisión real de 10 de abril de 1608, tras la muerte de su padre $^{37}$. Este último nombramiento facilitó la vuelta de don Jerónimo Pérez de Sayas al oficio de justicia que había ejercido hasta ese momento su cuñado, aunque resulta complicado entender por qué pasaron tres años hasta que fue nombrado por privilegio real dado en Aranjuez el 7 de mayo de $1611^{38}$. Seguramente, la explicación debamos buscarla en que desde febrero de 1607 en una consulta del Consejo de Aragón se proponían a los siguientes candidatos para el cargo de justicia: Jerónimo Pérez de Sayas, Jerónimo Campi (hijo del regente Campi), Justo de Torres (yerno del baile general), Juan de Latrás (señor de Latrás), Juan Baguer, Francisco Pérez de Oliván (gobernador de la Acequia Imperial), Francisco Abarca (señor de Gavín) y su hijo Francisco ${ }^{39}$

Estos iniciales cambios en los regidores que ocuparon la magistratura dieron paso a un periodo de estabilidad, ya que tras el nombramiento de don Jerónimo Pérez de Sayas en 1611 no se sucedieron importantes novedades hasta 1633. El 27 de noviembre de 1633 el monarca nombró por adjunto y futuro sucesor de don Jerónimo en el oficio de justicia de las montañas de Aragón y en los alcaidados a su hijo Valero. Este último,

36. GASCÓN PÉREZ, J. La rebelión..., op.cit., pp. 1302-1304.

37. AHPrZ. Fondo Argillo, caja 2187/32.

38. En esta fecha fue nombrado alcaide del valle de Tena; justicia de la villa de San Esteban de Litera, del valle de Ansó, del lugar de Salvatierra, de la villa de Boltaña, del valle de Gistau y de la villa de Ruesta; alcaide del castillo de Candanchú, alcaide del castillo de Ruesta y justicia o alcaide del valle de Aragüés del Puerto. Luego, el 7 de mayo de 1614 recibió el nombramiento de justicia de la villa de Biescas y Subirón. AHPrZ. Fondo Argillo, caja 2187/20-31 (leg. 79/ 20-31). AHPrH. Pedro Santapau, 1612, 5-IV, ff. 221r-221v. GóMEZ De VALENZUeLA, M. Estatutos y Actos Municipales..., op.cit., pp. 415-416.

Desconocemos por qué Manuel Gómez de Valenzuela dice que el 25 de julio de 1613 tomó posesión del cargo de justicia de las montañas de Jaca. Gómez De VALENZuela, M. La vida en el valle de Tena en el siglo XVII..., op.cit., p. 57.

39. GASCÓN PÉREZ, J. La rebelión aragonesa... op.cit., t. II, p. 1302. Este autor dice que en «una relación adjunta, sin data, se rechazaba como candidatos a los citados Latrás, Baguer y Abarca, por ser todos ellos cabezas del bando de las montañas». Pablo Desportes Bielsa informa que Francisco Abarca defendía sus derechos para ocupar el cargo haciendo alusiones a los servicios prestados en la guerra de Portugal, en Flandes y en el paso de Santa Elena -donde fue hecho prisionero por los franceses y saqueada su casa y dominios señoriales-. El interesado también recordaba que había perdido dos hijos en acciones de guerra y que estaba dispuesto a renunciar de los 30 ducados que tenía como merced real en Pamplona. Concluía afirmando que, si lograba el cargo, se sentía recompensado de todos los servicios y daños que había sufrido su casa -que importaban más de 12000 ducados-. DeSPORTES BIELSA, P. «El Justicia...», op.cit., p. 24. Información recopilada por el autor en A(rchivo) C(orona de) A(ragón), Consejo de Aragón, Secretaría de Aragón, legajo 36, documento 344. 
el 2 de diciembre de 1633 presentó al justicia de Aragón el privilegio original de su oficio como futuro sucesor de su padre ${ }^{40}$.

Don Jerónimo Pérez de Sayas -que fue comisario real de las ordinaciones de las villas altoaragonesas de Bolea en 1634 y de Alquézar en 1645-41debió de ocupar el cargo de justicia hasta 1637, cuando le sustituyó su hijo don Valero Pérez de Sayas y Heredia en circunstancias que desconocemos. Don Valero solamente ejerció el oficio en los años 1637-1644, ya que su prematura muerte el 26 de noviembre de 1644 dejó nuevamente vacante la plaza de justicia de las montañas de Aragón ${ }^{42}$.

Estos acontecimientos facilitaron que, por un privilegio real dado en Zaragoza el 20 de abril de 1645, el nuevo justicia fuese José de Sayas y Heredia, nieto de don Jerónimo, aunque este último tenía facultad de nombrar otra persona durante la minoría de edad de su nieto ${ }^{43}$. La realidad fue que desde 1644 y hasta 1657 el nuevo justicia fue el «viejo» don Jerónimo Pérez de Sayas ${ }^{44}$. Solamente la muerte de don Jerónimo el 7 de mayo de 1657 dejó el camino expedito para que ejerciese el oficio su nieto y heredero don José Pérez de Sayas. Éste juró el cargo ante el virrey el 13 de junio de $1657^{45}$ y dos días después ante el justicia de Aragón, comprometiéndose a guardar «los fueros, observancias, ussos y costumbres del dicho y presente Reyno de Aragón...» ${ }^{46}$. Don José Pérez de Sayas estuvo en el puesto hasta el 18 de octubre de 1672, cuando murió ${ }^{47}$. Con este fallecimiento también se extinguía - por un acuerdo ya establecido

40. AHPrZ. Fondo Argillo, caja 2187/17-19 (leg. 79/17-19). Tengamos en cuenta que como oficial real estaba obligado a jurar el cargo «conforme a Fuero» ante Su Majestad o sus representantes y ante el justicia de Aragón o sus lugartenientes. SAVAll, P. y PEnÉn, S. Fueros..., op.cit., tomo I, p. 421.

41. Las ordinaciones de Bolea fueron aprobadas por Su Majestad en Madrid el 29 de junio de 1634 y ratificadas en el concejo general de la villa el 28 de diciembre de 1635. AHPrH. Orencio Sanclemente, 1639, 14-XI, f. 110r. Jarque MARTíneZ, E. y SAlas AusÉnS, J.A. «Monarquía, comisarios,...», op.cit., p. 266.

42. Don Valero Pérez de Sayas y Heredia, el 26 de diciembre de 1638, atendiendo a una propuesta del monarca, preguntó en varias poblaciones altoaragonesas (Alcalá del Obispo, Fañanás, Argavieso, Albero Alto, Piracés, Arguis, Belsué, Panzano, Nocito, Torralba, Tardienta, Barbués, Novallas, Vicién y Albero Bajo) si había personas que podían servir en la guerra. AHPrH. Vicencio Santapau, 1639 (1638, 26-XII), ff. $4 \mathrm{r}-21 \mathrm{r}$.

43. Por dicho privilegio José de Sayas y Heredia se convirtió en justicia de Berdún, Bielsa, Biescas, valle de Tena, villa de San Esteban de Litera, villa de Boltaña, Salvatierra, Gistau,... Fue designado, justicia o alcaide de los valles de Basa y Serrablo, del valle de Aragüés del Puerto, del valle de Aísa y del valle de Hecho. También fue nombrado como justicia o baile de la villa de Adahuesca y como responsable de los alcaidados de los castillos de Candanchú y Ruesta. AHPrZ. Fondo Argillo, caja 2187/1-15 (leg. 79/1-15).

44. Manuel Gómez de Valenzuela cita a dos justicias diferentes con el nombre de Jerónimo Pérez de Sayas, cuando en realidad es la misma persona. Sitúa a Jerónimo Pérez de Sayas (II) en el periodo 1639-1657 y a don Valero Pérez de Sayas en los años 1637-1639. GómeZ De VALEnZUELA, M. La vida en el valle de Tena en el siglo XVII..., op.cit., p. 57.

45. AHPrZ. Fondo Argillo, caja 2187/16 (leg. 79/16).

46. AHPrZ. Fondo Argillo, caja 2147/61 (leg. 42/61).

47. AHPrZ. Fondo Argillo, caja 2169/11 (leg. 67/11). 
en las Cortes de 1645-1646- una magistratura que había tenido vida durante cerca de un siglo.

Esta relación de justicias de las montañas de Aragón nos está indicando que durante los años en que se mantuvo esta magistratura siempre estuvo en manos de una misma familia, lo que nos muestra muchas similitudes con la patrimonialización del cargo de justicia de Aragón ${ }^{48}$, durante largo tiempo en manos de los Lanuza. El que ambos oficios fuesen de nombramiento real y que apareciesen como defensores de los fueros aragoneses nos ponen en guardia sobre las conductas de sus titulares, ya que éstos podían jugar a «nadar y guardar la ropa» en cuanto que debían hacer compatibles la defensa de los «intereses aragoneses» recogidos en los fueros de Aragón y, como «estómagos agradecidos» de quien los había nombrado -recordemos que cobraban de los recursos económicos aragoneses-, debían atender los mandatos de la realeza, que podían ser coincidentes o no con los citados «intereses aragoneses». Además, el justicia de las montañas de Aragón debía rechazar las particularidades que ofrecían los estatutos locales de desaforamiento, con lo que entramos en el territorio de una posible y significativa contradicción política. Otra cosa es que consideremos «inconstitucionales» los desafueros, porque eliminaban las garantías procesales. Si esto ocurre, debemos empezar a pensar en la Monarquía como una defensora más de las «libertades» aragonesas. Por otra parte, falta mucho por concretar en respuesta a la pregunta sobre a quién «servía» verdaderamente el justicia de Aragón.

El personaje clave en el oficio de justicia de las montañas de Aragón fue don Jerónimo [Fernández] de Heredia y [Palomar ${ }^{49}$. Estamos hablando de la primera per-

48. Esta tendencia a la patrimonialización también existía en el oficio de gobernador de Aragón -de nombramiento real-.

49. Era hijo del segundo matrimonio de don Juan [Díez de Aux] Fernández de Heredia con doña Juana Palomar. Don Juan, quien fue señor de Cetina y Sisamón, estuvo casado en primeras nupcias con doña Jerónima de Liñán. Los padres y los abuelos de don Juan fueron don Juan Díez de Aux Fernández de Heredia y doña Aldonza Hurtado de Mendoza, señora de Sisamón, y don Luis Díez de Aux y doña Violante Fernández de Heredia, respectivamente. AHPrZ. Fondo Argillo, caja 2164/7 (leg. 62/7).

Gracias a la capitulación matrimonial - de fecha desconocida- de don Juan [Díez de Aux] Fernández de Heredia con doña Jerónima de Liñan -hija de don Miguel de Liñán, señor de Cetina y Contamina, y de la difunta doña Catalina de Granada, que se habían casado el 10 de marzo de 1509 en Molina de Aragón-, podemos interpretar mejor el acceso de esta familia a los dominios señoriales. El contrayente aportó - por donación de su madre- los 2.000 florines de oro que tenía de dote sobre el lugar de Sisamón, el dominio señorial de Sisamón con su jurisdicción civil y criminal y las cañadas y heredades del lugar de Iruecha (aldea de la villa castellana de Medinaceli). Doña Jerónima llevó al matrimonio 44.000 sueldos en dinero contado. El aporte de don Juan estaba sujeto a que no podía venderlo ni empeñarlo, ,.. y lo debía disponer en el hijo mayor del matrimonio o, en su defecto, en la hija mayor. AHPrZ. Fondo Argillo, caja 2164/14 (leg. 62/14).

Una información posterior nos indica que el dominio señorial de Sisamón pasó a un hijo de este matrimonio, llamado Juan, el 18 de septiembre de 1578. Poco tiempo debió de disfrutar del señalado dominio, ya que parece que murió en Cetina el 4 de mayo de 1585. A su vez, el donante lo había recibido de su 
sona que ocupó el puesto y luego propició que su hijo Juan y su yerno y paisano don Jerónimo Pérez de Sayas se convirtiesen en sus sucesores. Esta terna se vio favorecida - como ya hemos anticipado- porque en 1601 don Jerónimo Fernández de Heredia fue designado gobernador de Aragón y abrió otra puerta - con el permiso de la Monarquíaa la familia dentro de la administración, lo que facilitó que su hijo y posteriormente su nieto Pedro Pablo siguiesen sus pasos y liberasen el oficio de justicia de las montañas para quien era, respectivamente, yerno, cuñado y tío político suyo. Así pues, esta información nos permite recordar que los cargos de gobernador y justicia de las montañas quedaron bajo la órbita de los [Fernández de] Heredia durante buena parte del siglo XVII. Solamente la obligada renuncia en 1661 del gobernador don Pedro Pablo Fernández de Heredia, hijo y nieto de gobernadores, privó a la familia de perpetuarse más tiempo en el cargo ${ }^{50}$. Más puntual fue el abandono del cargo de justicia de las montañas, ya que se había establecido una fecha de caducidad y su hora final llegó en 1672 , cuando se produjo el óbito del que iba a ser el último ocupante.

El caballero mesnadero don Jerónimo Fernández de Heredia accedió a los oficios de justicia de las montañas y de gobernador porque cumplía los requisitos básicos de ser una persona natural y vecina de Aragón. Además, su condición de caballero mesnadero facilitó el nombramiento como regente de la General Gobernación de Aragón, algo que no sucedía con los infanzones - obligados a armarse caballeros para poder jurar el cargo-, con los caballeros de hábito - que debían abandonar tal condición mientras permaneciesen en el cargo- y con los miembros de la nobleza titulada -inhabilitados para el desempeño del oficio-. Precisamente, como ya lo hemos señalado en una nota, estos dos últimos supuestos los sufrió el nieto de don Jerónimo para poder ser gobernador y para abandonar el cargo tras convertise en conde de Aranda. Esto sin olvidarnos de que don Juan -el segundo gobernador de la familia- también hizo «dejación» del hábito militar para ejercer el cargo.

Lógicamente, además de cumplir con los requisitos expuestos, los Fernández de Heredia y sus nuevos parientes los Pérez de Sayas aparecen en la escena política como fieles servidores de la Monarquía, algo que les reportaba los consabidos beneficios de ocupar puestos de nombramiento real y otras mercedes.

También queremos plantear que la estrategia familiar que diseñó y puso en práctica don Jerónimo Fernández de Heredia le permitió configurar un grupo de poder fundado en unas cuidadas relaciones familiares y apoyadas en un significativo paisanaje

padre el 18 de febrero de 1557. AHPrZ. Fondo Argillo, caja 2164/27 (leg. 62/27); 2164/19 (leg. 62/19); caja 2164/10 (leg. 62/10).

50. Con la renuncia del conde de Aranda Pedro Pablo se rompía una pequeña patrimonialización del oficio de gobernador de Aragón, en manos de los [Fernández de] Heredia durante tres generaciones. Por ello, no entendemos que Guillermo Redondo Veintemillas y Alberto Montaner Frutos puedan hablar de «la definitiva patrimonialización del cargo en el siglo XVII». REDONDO VEINTEMILLAS, G. y MONTANER FRUTOS, A. «De re sigillographica aragonensia: el sello del gobernador de Aragón Francisco de Gurrea (1531-1554)», Anales de la Real Academia Matritense de Heráldica y Genealogía, $\mathrm{n}^{\circ}$ 8, vol. 2 (2004), pp. 727-731. 
de individuos de la ciudad de Calatayud y de las poblaciones próximas. Todo empezó cuando don Jerónimo casó en primeras nupcias con doña Ángela de Rueda y fruto de esa unión nacieron don Juan Fernández de Heredia y Rueda -que casó con doña Ana Luisa Zapata y Urrea ${ }^{51}$, doña Violante Fernández de Heredia y Rueda - que contrajo nupcias con don Jerónimo Pérez de Sayas- y don Jerónimo Fernández de Heredia y Rueda, quien fue canónigo de la Metropolitana de Zaragoza ${ }^{52}$. Tras enviudar de doña Ángela de Rueda don Jerónimo contrajo segundas nupcias con doña Petronila de Nueros y procreó a doña Francisca Fernández de Heredia, quien murió siendo niña ${ }^{53}$.

La capitulación matrimonial del «segundón» don Jerónimo Fernández de Heredia y doña Ángela de Rueda fue pactada a finales de febrero y el día 1 de marzo de $1579^{54}$. Fueron desposados en Saviñán el 16 de marzo de $1579^{55}$. Don Jerónimo aportó al matrimonio lo siguiente: el término de Las Cañadas en Sisamón y unas casas en la misma población, unas casas y 14 hanegas de tierra en Calatayud, 2.500 sueldos jaqueses de renta con 50.000 sueldos de propiedad en un censal emitido por los señores de Sisamón, los 80.000 sueldos jaqueses que le debía el Concejo de Sisamón y 3.500 sueldos jaqueses de renta anual que le adeudaba su hermano Juan. Doña Ángela de Rueda llevó al matrimonio varias fincas rústicas y urbanas vinculadas en Épila, 6.040 sueldos jaqueses de renta y 123.500 sueldos de propiedad en censales sobre diversos concejos aragoneses (Zaragoza, Villarroya, Cadrete, Ayerbe y sus aldeas, Utebo, Mesones de Isuela, Bardallur, Rivas-Ejea de los Caballeros, Fuentes de Jiloca, Tierga, Gallur, Escatrón, Abanto, Mara y Castejón...), pequeñas sumas monetarias en censales cargados sobre haciendas de particulares y 30.000 sueldos jaqueses en oro, plata, joyas y otros bienes muebles. Entre los diversos pactos acordados destacan los que reconocían para don Jerónimo una viudedad foral en los bienes de Épila, en los treudos perpetuos de la villa de Épila y en 1.000 sueldos de renta de los censales aportados por su espo-

51. Firmaron las capitulaciones matrimoniales en Calatayud el 25 de septiembre de 1611. Los sucesivos herederos de este matrimonio fueron el conde de Aranda don Pedro Pablo Fernández de Heredia y Zapata -casado en 1638 con doña María Josefa Oriola [olim de Vera]-, don Dionisio [Fernández] de Heredia -casado con doña Juana de Rocaful y Rocabertí- y doña Antonia [Fernández] de Heredia -casada con don Guillén, conde de Perelada-. AHPrZ. Fondo Argillo, caja 2101/12 (leg. 1/12).

52. El 8 de mayo de 1591 los hermanos Juan, Jerónimo y Violante eran menores de catorce años. AHPZ, Juan Escartín, 1591, 8-V, ff. 216v-218r. Tenemos constancia de que el 7 de octubre de 1624 don Jerónimo [Fernández] de Heredia era canónigo en la citada iglesia zaragozana. AHPrH. Pedro Santapau, 1624, 7-X, ff. 492r-497r.

53. AHPrZ. Fondo Argillo, caja 2164/7 (leg. 62/7).

54. En la capitulación matrimonial realizada el 1 de marzo de 1579 intervino por parte de don Jerónimo su hermano paterno don Juan Fernández de Heredia y Liñán, señor de Sisamón, Cetina y Contamina -casado con doña María de Andrade-y dos sobrinos de doña Ángela, llamados Miguel de Heredia y Hernando de Rueda, ya que sus padres -don Hernando de Rueda y doña Magdalena de Pasamonte, domiciliados en Calatayud- habían fallecido. AHPrZ. Fondo Argillo, caja 2119/20 (leg. 18/45); caja 2148/38 (leg. 43/38).

55. AHPrZ. Fondo Argillo, caja 2148/39 (leg. 43/39). 
sa. Doña Ángela tenía viudedad foral en todos los bienes de don Jerónimo y en 1.500 sueldos de renta anual de los que llevó al matrimonio su marido.

El matrimonio de don Jerónimo y doña Ángela se rompió por el óbito de esta última en Huesca el 23 de octubre de $1590^{56}$, cuando su marido era justicia de Jaca y de las montañas de Aragón. Doña Ángela, tres días antes de este fatal desenlace, estando enferma en la cama, escrituró las últimas voluntades -sin poder firmar por estar impedida- ${ }^{57}$.

Los poco más de once años de convivencia de don Jerónimo y doña Ángela dejaron unos descendientes directos que posteriormente llegaron a encumbrar a la familia. Además, la muerte de doña Ángela con hijos vivos propició que los nada despreciables bienes que aportó al matrimonio pasasen a engrosar el menguado patrimonio que había llevado el esposo.

La juventud de los hijos nacidos en el matrimonio no justifica completamente el que, antes de pasar un año desde el óbito de doña Ángela de Rueda, su esposo viudo contrajese nuevas nupcias. Así, el 3 de julio de 1591, con licencia del vicario general, fueron desposados por palabras de presente, en la casa zaragozana de doña María Pérez de Nueros, el caballero don Jerónimo Fernández de Heredia y doña Petronila de Nueros -hija del infanzón Diego de Nueros y doña María Pérez de Arnal-. Los testigos fueron el abogado fiscal micer Jerónimo Pérez de Nueros y don Francisco de Altarriba y Alagón, señor de Huerto ${ }^{58}$. Desconocemos cuándo recibieron las bendiciones nupciales. Por el contrario, sabemos que la capitulación matrimonial la firmaron en Zaragoza el 18 de mayo de $1591^{59}$, estando el contrayente residiendo en la villa de Sisamón ${ }^{60}$.

56. AHPrH. Martín Arascués, 1590, 23-X, f. 160r. AHPrZ. Fondo Argillo, caja 2148/18 (leg. 43/18).

57. AHPrH. Martín Arascués, 1590, 20-X, f. 160r (1r-2r). AHPrZ. Fondo Argillo, caja 2148/15, 18 y 24 (leg. $43 / 15,18$ y 24). Doña Ángela en su testamento establecía lo siguiente: su cuerpo debía ser sepultado en el lugar que le pareciese a su esposo. Daba una herencia legítima de 10 sueldos en bienes muebles y 10 sueldos en bienes inmuebles a cada uno de sus tres hijos vivos. Al convento de monjas bernardas de Trasobares -donde la testadora estuvo algunos años- le daba un albarán de 400 ó 500 escudos. Dejaba 40.000 sueldos a cada uno de sus hijos Jerónimo y Violante, con la condición de que, si morían sin hijos legítimos, el dinero debía ir a parar al heredero universal dispuesto por la testadora. Si Violante era monja -algo que no ocurrió- solamente debía recibir 1.000 escudos durante su vida, suma que una vez muerta debía volver a su hermano Jerónimo. Su marido tenía viudedad en la hacienda hasta que se casase su hijo Juan Fernández de Heredia y Rueda, el heredero universal. Nombró como tutores, curadores y ejecutores testamentarios a su marido, a su sobrino Miguel de Heredia y a fray Miguel Andrés Terrer. Las cláusulas debieron de propiciar que don Jerónimo Fernández de Heredia tuviese que participar en una sentencia arbitral con sus hijos AHPZ. Juan Escartín, 1591, 10-V, ff. 222r-251r.

58. A(rchivo) D(iocesano de) Z(aragoza), Quinque libri de la provincia de la Seo de Zaragoza, tomo $2^{\circ}$., f. 604.

59. AHPZ. Juan Escartín, 1591, 18-V, ff. 277r-297r. AHPrZ. Fondo Argillo, caja 2119/22 (leg. 18/47).

60. AHPZ. Juan Escartín, 1591, 9-VII, ff. 448v-449v. El caballero don Diego [Fernández] de Heredia, a los pocos meses de esta actuación, participó con don Francisco Abarca, señor de Gavín, en la defensa del paso de Santa Elena en el Pirineo contra la invasión bearnesa. Ambos fueron apresados el 9 de febrero de 1592 y fueron conducidos al castillo de Lourdes en Bearne. LEONARDO DE ARGENSOLA, L. Información de los sucesos..., op.cit., p. 152. 
Su estancia en Sisamón debía de estar relacionada con que en esos días don Jerónimo y su hermano don Diego [Fernández] de Heredia, caballero de la orden de San Juan de Jerusalén, como tutores y curadores de su sobrino don Juan Fernández de Heredia [y Andrade] y Liñán, menor de 14 años, señor de Cetina, Sisamón y Contamina, estaban procediendo al nombramiento de justicias de los distintos lugares del señorío.

Don Jerónimo aportó al matrimonio los siguientes bienes: unas casas en Sisamón, unas casas en la parroquia de San Andrés de Calatayud, otras casas en la parroquia de San Andrés de Calatayud, la partida de las Cañadas en los términos del lugar de Urriecha (Castilla) -confrontaba con Sisamón-, 4.284 sueldos de pensión con 60.000 sueldos de propiedad que había cargado sobre las personas y bienes de los marqueses de Almazán, dos censos sobre los lugares de Argal y Mochales, un censal de 1.500 sueldos de pensión con 50.000 sueldos de propiedad que fue vendido por don Juan Fernández Liñán de Heredia -señor de Cetina y Sisamón-, un censal de 1.000 sueldos de pensión con 20.000 sueldos de propiedad -cargado sobre los lugares de Híjar, Belchite, La Puebla de Albortón, Almonacid de la Cuba, Lécera, Urrea de Gaén y La Puebla de Híjar-, 60.000 sueldos que el señor de las villas de Cetina y Sisamón reconoció tener en comanda del contrayente, 200 ducados de renta anual sobre las rentas de la tesorería general del Reino de Nápoles que recibió de merced de Su Majestad, 16.000 sueldos que le debía el rey por un servicio y 54.000 sueldos en diversos bienes muebles y caballos. Doña Petronila llevó al matrimonio, por donación de su madre -y usando el poder dado por su difunto marido-, lo siguiente: 5.000 sueldos de renta con 100.000 sueldos de propiedad en varios censales (cargados sobre Nonaspe, Épila, Rueda, Urrea de Jalón, Almonacid de la Sierra, Rodén, Murillo de Gállego, Cetina, Ariza y sus tierras), 4.000 sueldos de dinero contado -incluidas las pensiones de los censales-para el día que oyesen misa nupcial y todos los otros bienes que le pudiesen pertenecer ${ }^{61}$.

En este enlace, más que en el patrimonio que aportó la contrayente, debemos fijarnos en su significado social. El caballero Fernández de Heredia se estaba casando con la nieta del abogado fiscal de la familia bilbilitana de los Nueros y estaba emparentan-

61. Se estableció que doña Petronila no podía disponer de los 100.000 sueldos de la dote nada más que en hijos suyos o descendientes de ellos legítimos y de legítimo matrimonio. Muriendo sin hijos, dicha suma debía ser para su madre doña María Pérez de Arnal y sucesivamente en Diego de Nueros -hermano de la contrayente- y sus sucesores. En este vínculo se daba poder a doña Petronila para que puediese disponer de dicha dote hasta 10.000 sueldos jaqueses.

Don Jerónimo aseguraba a su futura esposa la citada dote de 100.000 sueldos y un excrex y aumento de dote de 33.333 sueldos y cuatro dineros, con la obligación de que dispusiese dicho excrex en hijos del matrimonio y, si moría sin hijos, pudiese disponer 10.000 sueldos en quien quisiera y el resto del dinero fuese para los herederos de don Jerónimo Fernández de Heredia. Tuvo validez la cláusula que establecía que las joyas y vestidos de doña Petronila debían ser para su hija. Don Jerónimo Fernández de Heredia debía vincular para sus hijos la suma de 90.000 sueldos jaqueses, para repartirlos según le pareciese. Si Petronila sobrevivía a su marido, debía tener una viudedad foral de 7.000 sueldos de renta anual en los bienes de su marido. Si sobrevivía don Jerónimo a su esposa, debía tener viudedad en los 90.000 sueldos. 
do con los Pérez de Nueros, destacados miembros de la magistratura en Aragón - de lo que volveremos a dar cuenta más adelante- y personas vinculadas a la Monarquía.

Una vez que se cumplieron tan importantes objetivos, no importaba tanto que el matrimonio se rompiese por la muerte de don Jerónimo Fernández de Heredia, en ese momento gobernador de Aragón, en algún momento de 1608. Doña Petronila de Nueros falleció el 27 de abril de 1623, en Huesca, en las casas que fueron de su esposo y de ella en la «placeta» Nueva, confrontantes con una casa de Pascual de Falces y Gallur. El reconocimiento del cadáver lo hizo su hijastro político don Jerónimo Pérez de Sayas, justicia de las montañas de Aragón ${ }^{62}$. Las últimas voluntades las firmó doña Petronila el 26 de abril de $1623^{63}$, un día antes de morir.

Si el caballero don Jerónimo Pérez de Sayas y Liñán de Vera -alias Juan de Liñán de Vera y Salazar- ${ }^{64}$ accedió al oficio de justicia de las montañas de Aragón fue como consecuencia de su enlace matrimonial con la ya citada doña Violante Fernández de Heredia y Rueda, ya que su suegro le abrió todas las puertas necesarias para ello. Don Jerónimo -quien era hijo y heredero universal del caballero Juan Miguel Pérez de

62. AHPrH. Pedro Santapau, 1623, 27-IV, ff. 182v-183r.

63. AHPrH. Pedro Santapau, 1623, 26-IV, ff. 176r-181v. En ese momento, doña Petronila era la heredera universal de los bienes de su difunta madre doña María Pérez Arnal, la heredera universal y ejecutora testamentaria de los bienes de su hermano don Diego de Nueros y la ejecutora testamentaria de los bienes de su hermana doña Violante de Nueros, domiciliados en Zaragoza. AHPrH. Pedro Santapau, 1623, 7-III, ff. 110r-111r; 1623, 16-IV, ff. 159v-160r.

La testadora solicitaba lo siguiente: deseaba ser enterrada con el hábito de carmelita en la iglesia del convento del Carmen de Huesca, en la parte del convento que señalasen los frailes. La defunción y honras fúnebres se debían celebrar con el capítulo de la Seo de Huesca; al día siguiente de las honras, los frailes del convento del Carmen estaban obligados a celebrar una misa cantada y responsos. También se debían celebrar por su alma 1.500 misas. Dejaba 500 sueldos al convento de los padres capuchinos y 1.000 sueldos al Hospital de Huesca. Donaba 1.000 sueldos para la construcción de la iglesia parroquial de San Lorenzo en Huesca -templo que fue inaugurado a finales de septiembre de 1624-. Pedía a sus ejecutores testamentarios que tomasen 500 escudos para edificar una capilla y retablo bajo la advocación de la Inmaculada Concepción en la iglesia del convento oscense del Carmen -con el que el 19 de mayo de 1615 había firmado una concordia sobre la fundación de una misa perpetua y otros sufragios-. Donaba 4.000 sueldos al convento de monjas carmelitas calzadas de Huesca para la obra de dicho convento en la iglesia de San Miguel. Dejaba a su hijastra doña Violante Fernández de Heredia -«en señal de amor»- un «quadrico», una silla bordada de carmesí, cuatro sillas bajas de terciopelo negro y un cofre. Donaba a su nietastra doña Francisca Pérez de Sayas - «por lo mucho que la quiero»- la suma de 1.500 escudos. Solicitaba que se restituyese toda la plata que se le debía al marido de su hijastra don Jerónimo Pérez de Sayas. También encargaba la entrega de pequeños regalos a distintos particulares e instituciones. Nombraba como ejecutores testamentarios a don Juan Fernández de Heredia, gobernador de Aragón, a don Jerónimo Fernández de Heredia, canónigo de la Seo de Zaragoza, a don Jerónimo Pérez de Sayas, justicia de las montañas de Aragón, a doña Violante Fernández de Heredia, a mosén Domingo Morer, vicario de la Seo de Huesca, al prior del convento del Carmen de Huesca y al notario Pedro Santapau. Dejaba heredera a su «Alma» para que sus ejecutores gastasen la herencia en misas, limosnas, sufragios y obras pías.

64. AHPrZ. Fondo Argillo, caja 2147/43 (leg. 42/43). 
Sayas $^{65}$ y de doña Agustina [Liñan y] de Vera $^{66}$, domiciliados en Calatayud ${ }^{67}$, ciudad donde debió de nacer nuestro justicia-, firmó en Zaragoza los capítulos matrimoniales con doña Violante el 28 de mayo de 1598. En dicho contrato Jerónimo aportó al matrimonio hasta la suma de 300.000 sueldos que le dio su padre. Éste, mientras viviese, se obligaba a mantener en su casa y compañía a los futuros cónyuges y a los hijos que Dios les diere a sus propias costas. En el supuesto de que por algún motivo no quisiese tener en su casa y compañía a los futuros cónyuges y a sus hijos, prometió y se obligó a darles anualmente -mientras viviese- setenta cahíces de trigo, 8.000 sueldos jaqueses - pagaderos anticipadamente cada cuatro meses-y las alhajas y muebles de casa que le pareciere a Juan Miguel. Los futuros cónyuges también debían tener para sí los 23.187 sueldos en los censales que doña Violante llevaba como dote y el dicho Juan Miguel Pérez de Sayas debía pagar la renta anual de dichos títulos a razón del cinco por ciento. Juan Miguel Pérez de Sayas podía gozar, poseer y usufructuar para su beneficio y utilidad todos los bienes maternos de su hijo que fueron de la difunta doña Agustina de Vera, su primera mujer. Don Jerónimo Pérez de Sayas Liñán de Vera también aportaba en ayuda del matrimonio lo que doña Inés de Granada -su madrastra- le daba para después de sus días; donación que consistía en los 16.000 sueldos que Juan Miguel Pérez de Sayas, su marido, le aseguró y firmó por excrex y aumento de dote, con la sola condición de cumplir lo estipulado en las últimas voluntades. Finalmente, don

65. El privilegio real que reconocía a Juan Miguel Pérez de Sayas como caballero fue otorgado en Binéfar el 9 de diciembre de 1585. AHPrZ. Fondo Argillo, caja 2163/2 (leg. 61/2). Juan Miguel era hermano de Alonso Pérez de Sayas, canónigo de la iglesia colegial de Santa María de Calatayud, y de Juana Pérez de Sayas, casada con García Remírez. El canónigo murió el 9 de octubre de 1585, habiendo testado unos años antes y habiendo nombrado heredero a Juan Miguel. AHPrZ. Fondo Argillo, caja 2147/57 (leg. 42/57).

66. Doña Agustina, natural del lugar de Villarroya de la Sierra, ya había fenecido el 3 de junio de 1580 . Hizo testamento -que sirvió de últimas voluntades-en Calatayud el 13 de septiembre de 1579. AHPrZ. Fondo Argillo, caja 2131/18 (leg. 28/25).

67. AHPrZ. Fondo Argillo, caja 2119/21, (leg. 18/34). AHPr.H. Pedro Santapau, 1627, 22-VII, f. 346v; 1627, 5-VIII, ff. 382r-383r. Juan Miguel Pérez de Sayas, tras la muerte de Agustina, su primera esposa, se casó en segundas nupcias con doña Inés de Granada, firmando la capitulación matrimonial el 1 de septiembre de 1582. Desconocemos el momento puntual del fallecimiento de Juan Miguel y solamente sabemos que el óbito ya se había producido el 22 de julio de 1627. Firmó sus últimas voluntades el 11 de julio de 1618 ante el notario bilbilitano Juan Miguel Tris.

El caballero Juan Miguel Pérez de Sayas, domiciliado en Calatayud, pidió en su testamento que su cuerpo muerto fuese sepultado en la iglesia de San Francisco de Calatayud, en su capilla, a la entrada de la sacristía. Nombró heredero universal a su hijo don Jerónimo Pérez de Sayas y dejó una herencia legítima de 5 sueldos jaqueses en bienes muebles y 5 sueldos jaqueses en bienes inmuebles. Los ejecutores testamentarios eran su cuñado García Remírez de Ateca, su sobrino don Toribio Remírez de Ateca, ambos domiciliados en Ateca, y su hijo Jerónimo Pérez de Sayas. AHPrZ. Fondo Argillo, caja 2148/20 (leg. 43/20).

Doña Inés de Granada y Heredia, domiciliada como su marido en Calatayud, murió el 14 de mayo de 1608 en la vivienda que tenía el matrimonio en la parroquia bilbilitana de Santa María. Doña Inés había testado el 27 de septiembre de 1605 ante el notario de Calatayud Diego de la Cal. AHPrZ. Fondo Argillo, caja 2147/11 (leg. 42/11). 
Jerónimo Pérez de Sayas aportó los bienes que fueron de su difunta madre Agustina de Vera y que le pertenecían como heredero.

Doña Violante Fernández de Heredia llevó, y su hermano don Juan Fernández de Heredia -como heredero universal que era de los bienes que fueron de su madre, la difunta Ángela de Rueda- le dió, los 40.000 sueldos que le dejó la madre de ambos (en un censal de 500 sueldos de pensión anual y 11.000 de propiedad sobre el lugar de Villarroya, 415 sueldos y 8 dineros de pensión con 8.313 de propiedad sobre el lugar de Utebo, 200 sueldos de pensión con 4.000 sueldos de propiedad sobre los terratenientes de la Vega de Meli en Calatayud, 175 sueldos de pensión con 3.500 de propiedad sobre el Concejo de Alarba y 13.187 sueldos para llegar a la citada suma). También aportó y su padre le dió 30.000 sueldos jaqueses -cargados en censales sobre el lugar de Cetina-, 10.000 sueldos como donación propter nuptias - que se los pagaría dentro de los cinco años siguientes al otorgamiento de la capitulación matrimonial- y 20.000 sueldos jaqueses en las pensiones de sus censales. Doña Violante llevó al matrimonio las joyas que le daba doña Inés de Granada y los bienes que pertenecieron a los difuntos Francisco Granada y don Miguel Granada, padre y hermano de Inés, situados en Paracuellos de Jiloca, con la obligación de pagar 43.000 sueldos a Juan Miguel Pérez de Sayas ${ }^{68}$.

El matrimonio Pérez de Sayas-Fernández de Heredia se rompió, tras veintisiete años de convivencia, con la muerte de doña Violante el 22 de marzo de 1625. El óbito se testificó notarialmente estando el cadáver en unas casas de su marido, situadas en la calle de los Caballeros, en la parroquia de la Seo de Huesca ${ }^{69}$, ciudad donde residía habitualmente la unidad familiar.

Antes de la ruptura matrimonial por el óbito de doña Violante, los cónyuges procrearon dos hijos vivos, llamados Valero y Francisca $^{70}$. Esta última estuvo casada en primeras nupcias con don Juan de Bardaxíolim Muñoz de Gamboa, matrimonio que fue

68. Juan Miguel Pérez de Sayas y don Jerónimo Pérez de Sayas aseguraban a doña Violante Fernández de Heredia los censales y los 23.187 sueldos como bienes suyos dotales. Don Jerónimo aseguraba a su futura mujer un excrex y aumento de dote de 40.000 sueldos jaqueses, con la obligación de disponer de dicha suma en hijos del matrimonio y, si no los hubiere, solamente podía disponer de 20.000 sueldos y los restantes debían volver a don Jerónimo Pérez de Sayas. Si sobrevivía doña Violante con hijos, debía disponer de 6.000 sueldos para comprar las alhajas y muebles que le pareciere. La disolución del matrimonio quedando viva doña Violante le permitía a ésta sacar todos sus vestidos, joyas y arreos. Doña Violante no estaba obligada a contribuir en deudas algunas que hubiere con la disolución del matrimonio y tenía derecho, si se quedaba viuda, a la viudedad foral sobre los bienes y hacienda de los dichos Juan Miguel Pérez de Sayas y don Jerónimo Pérez de Sayas en la suma y cantidad de 30 cahíces de trigo, 8.000 sueldos de renta anual y habitación en un cuarto de las casas principales de Juan Miguel Pérez de Sayas -situadas en la plaza Múñez de Calatayud- o 500 sueldos de renta anual mientras éste y su esposa viviesen. Ni doña Violante ni los suyos, tenían derecho a los trescientos mil sueldos que se reservaba Juan Miguel Pérez de Sayas. AHPZ. Diego Fecet, 1598, 28-V, ff. 673v-708r. AHPrZ. Fondo Argillo, caja 2148/31 (leg. 43/31); caja 2106/29 (leg. 6/2).

69. AHPrH. Pedro Santapau, 1625, 22-III, f. 201r.

70. Si hacemos caso a una copia de datos del siglo XVIII, en la iglesia parroquial de San Andrés de Calatayud el día 2 de febrero de 1600 fueron bautizados los hermanos don Juan Miguel Pérez de Sayas y don 
regulado por una capitulación matrimonial de 23 de diciembre de $1626^{71}$. De este enlace nacieron doña Bernarda Margarita y doña Juana María ${ }^{72}$. En segundas nupcias, doña Francisca Pérez de Sayas y Fernández de Heredia se casó con don Pedro Nicolás de Balmaseda, caballero del hábito de Montesa, domiciliado en Zaragoza. La capitulación matrimonial la firmaron el 18 de noviembre de 1634 ante el notario zaragozano Juan Jerónimo Navarro ${ }^{73}$. Don Pedro Nicolás de Balmaseda y Cerezo $^{74}$ aportó un importante patrimonio rústico y urbano en la villa zaragozana de Ejea de los Caballeros, 20.000 sueldos en dinero contado, 80.000 sueldos en joyas y otros objetos, y el usufructo que tenía de los bienes y hacienda de su primera y difunta esposa doña Antonia de Oro. Por su parte, doña Francisca de Sayas y Heredia llevó al matrimonio los 30.000 sueldos jaqueses que le pertenecían por el último testamento de doña Petronila de Nueros, la parte de los bienes que le correspondían de la herencia de su madre doña Violante Fernández de Heredia, la dote y excrex que le firmó su primer esposo, 150 cahíces de trigo, 800 libras jaquesas en plata y 60.000 sueldos jaqueses en joyas y diversos productos y deudas.

A los pocos meses de este acuerdo, más concretamente el 10 de marzo de 1635 , doña Francisca hizo un testamento donde establecía diversos deseos para después de su muerte ${ }^{75}$.

Por otra parte, don Valero Pérez de Sayas y Fernández de Heredia, hermano de doña Francisca, domiciliado en Huesca, contrajo nupcias con la zaragozana doña Luisa de Sora, viuda del difunto infanzón don Manuel Jerónimo de Contamina. El padre del contrayente y don Juan Luis de Sora, en nombre de su hija, actuaron como representantes de los futuros esposos a la hora de firmar la capitulación matrimonial el 24 de octubre de $1631^{76}$. Don Valero llevó al matrimonio los 10.000 sueldos de renta perpe-

Jerónimo Valero Pérez de Sayas, actuando como padrinos Gaspar de Sayas y doña María Zapata y Juan Pérez Ferrer y doña Isabel de Sayas, respectivamente. AHPrZ. Fondo Argillo, caja 2119/29 (leg. 18/29).

71. La capitulación matrimonial de 23 de diciembre de 1626 fue escriturada ante el notario zaragozano Francisco Morel y está en paradero desconocido. Dos años antes, más concretamente el 21 de junio de 1624, doña Francisca [Pérez] de Sayas y Heredia, siendo doncella y habitando en Huesca, nombró procurador a su padre. AHPrZ. Fondo Argillo, caja 2107/3 (leg. 7/3).

72. AHPrH. Pedro Santapau, 1627, 5-VIII, f. 383r. AHPrZ. Fondo Argillo, caja 2175/2 (leg. 70/2). AHPZ. Miguel Juan Montaner, 1635, 10-III, ff. 518r-530r.

73. AHPZ. Juan Jerónimo Navarro, 1634, 18-XI, ff. 3791-3807.

74. Este caballero, diputado del Reino de Aragón, en las Cortes de Zaragoza de 1645-1646 obtuvo el hábito de la orden de Santiago para su hijo José Nicolás de Balmaseda y de Oro «en compensación a los servicios prestados a la Corona». SANZ CAMAÑES, P. «Del Reino a la Corte. Oligarquías y élites de poder en las Cortes de Aragón a mediados del siglo XVII», Revista de Historia Moderna. Anales de la Universidad de Alicante, $\mathrm{n}^{\circ} .19$ (2001), p. 228

75. AHPrZ. Fondo Argillo, caja 2175/2 (leg. 70/2). AHPZ. Miguel Juan Montaner, 1635, 10-III, ff. 518r530r.

76. AHPrZ. Fondo Argillo, caja 2175/43 (leg. 70/43). caja 2136/12 (leg. 33/64); caja 2119/14 (leg. 18/14); caja 2112/1 (leg. 12/1). AHPZ. Juan Lorenzo Escartín, 1631, 24-X, ff. 984v-988v; Pedro Sánchez del Castellar, 1631, 24-X, ff. 1098r-1115v. 
tua que le daba su padre para cuando se celebrase la ceremonia nupcial ${ }^{77}$. Doña Luisa aportó varios bienes inmuebles en Zaragoza, la renta de diversos censales y alguna puntual donación ${ }^{78}$. Llevó joyas y vestidos por valor de 1.500 libras jaquesas. También contribuyó con los 1.000 escudos que tenía en la Tabla de Depósitos de Zaragoza, los 60.000 sueldos que le daba su abuela Isabel de Bordalba para cuando finalizasen sus días y los 150 escudos que le cedía su padre ${ }^{79}$.

Fruto de la unión carnal de don Valero y doña Luisa nació un varón que fue bautizado en la Seo de Zaragoza el 23 de mayo de 1635 con el nombre de don Jusepe Francisco Antonio Pérez de Sayas y de Sora ${ }^{80}$. También procrearon una hija llamada Teresa, de la que desconocemos la fecha de su nacimiento.

Trece años y un mes vivieron juntos don Valero y doña Luisa de Sora, ya que el 26 de noviembre de 1644 se produjo el óbito del cabeza de familia en sus casas zaragozanas de la calle y parroquia de Santa Engracia ${ }^{81}$. Antes de que llegase tan fatal desenlace, el padre del difunto debió de pedir la intercesión de santa Orosia para salvar a su hijo de la muerte. Así lo interpretamos cuando el 24 de junio de 1644 el notario real Agustín Pérez - en nombre de don Jerónimo Pérez de Sayas, padre de Valero- entregó a la iglesia parroquial de Yebra de Basa «un plato de lámpara, con todas sus cadenas y colgaduras de plata, puesto y esculpido en él un escudo de sus armas», para honrar a santa Orosia, y que debía ser colgado en el altar mayor de dicha iglesia enfrente del nicho donde estaba guardada la reliquia y cabeza de la santa ${ }^{82}$. El caballero don Valero

77. Esta renta estaba compuesta por 9.000 sueldos del salario de justicia de don Jerónimo Pérez de Sayas y los 1.000 sueldos restantes de los bienes del donante.

78. El patrimonio que llevó la contrayente fue el siguiente: unas casas y huerto en la población de San Mateo de Gállego. Las propiedades urbanas y rústicas en Zaragoza que especificamos a continuación: unas casas en la parroquia de la Magdalena, otras casas en la parroquia de San Andrés, dos portales de casas en la parroquia de San Miguel, dos casas en la parroquia de San Felipe, una casa y horno de cocer pan en la plaza del Estudio Mayor, una huerta en Ranillas, una viña en el plano de las Fuentes, una viña en Miralbueno, un olivar en la Adula del Martes y un olivar en la Romareda. Las rentas de los siguientes censales: 1.000 sueldos pagaderos por el Concejo de Huesca, 500 sueldos, 2.000 sueldos sobre Maella, 500 sueldos sobre Urrea de Gaén, Híjar y la Puebla de Híjar, 2.000 sueldos sobre Agüero, 1.050 sueldos sobre el estado de Fuentes, 500 sueldos sobre el marquesado de Camarasa, 1.000 sueldos sobre Erla, 500 sueldos sobre Épila, 1.000 sueldos sobre Bárboles y 2.000 sueldos sobre Pedrola.

79. Se pactó que doña Luisa o los suyos, en caso de disolución del matrimonio, podían recuperar los bienes aportados al matrimonio. Las joyas y vestidos debían ser para el sobreviviente. Si sobrevivía doña Luisa podía tomar el coche con mulas o caballos, si los hubiese, una cama y una colgadura de tapicería. Don Jerónimo Pérez de Sayas aseguraba a doña Luisa 500 libras jaquesas que podía gozar de viudedad. Los futuros cónyuges tenían viudedad en los bienes del otro.

80. ADZ. Quinque libri de la parroquia de la Seo de Zaragoza, libro de bautizados, tomo $3^{\circ}$., p. 302. AHPrZ. Fondo Argillo, caja 2119/11 (leg. 18/11).

81. AHPrZ. Fondo Argillo, caja $2175 / 51$ (leg. 70/51); caja 2135/43 (leg 33/63). AHPZ. Francisco Abiego, 1644, 26-XI, ff. 2604r-2606r.

82. AHPrZ. Fondo Argillo, caja 2147/24 (leg. 42/24). 
de Sayas y Heredia testó el 14 de noviembre de dicho año ${ }^{83}$ y solicitaba lo siguiente: quería que su cuerpo muerto fuese enterrado sin pompa en la capilla de San Juan Bautista de la iglesia zaragozana de Santa Engracia. Reservaba una herencia legítima de 5 sueldos en bienes muebles, 5 sueldos en bienes sitios y sendas arrobas de tierra en los montes de Zaragoza para sus hijos José y Teresa. Dejaba a su esposa como usufructuaria de sus bienes y como heredera fideicomisaria -conjuntamente con su padre- de los bienes de los hijos del testador y suyos, con la obligación de que dispusiesen la herencia en los citados descendientes «en qual más en qual menos» ${ }^{84}$.

Doña Luisa de Sora casó en terceras nupcias con don Juan de Vera Cabeza de Vaca, ciudadano de Zaragoza. Tenemos constancia de que el matrimonio seguía unido en julio de 1662 .

La repentina desaparición de don Valero dejaba como sucesor a un varón de nueve años, lo que supuso que nuevamente volvió a la escena política y familiar durante trece años don Jerónimo Pérez de Sayas, padre del difunto. Estamos hablando de don Jerónimo Pérez de Sayas, quien aglutinó en su persona el cargo de justicia de las montañas de Aragón y, por herencia familiar, el dominio señorial de Pomer -aunque debemos puntualizar que era señor jurisdiccional de la mitad de dicho lugar, ya que la otra mitad era del conde de Aranda $-{ }^{85}$. El dominio señorial ${ }^{86}$ llegó a los Pérez de Sayas gracias al matrimonio de Juan Miguel con doña Agustina [Liñán y] de Vera, ya que Pomer había pertenecido a la familia Vera y doña Agustina se había convertido en la heredera del señorío por los siguientes acontecimientos familiares: el 2 de junio de 1568 el dueño del señorío era Juan Liñán y de Vera, su tío, quien no tuvo descendencia directa de su matrimonio ${ }^{87}$. Ante este hecho, los nuevos dueños del señorío fueron los hijos de su hermano Martín y de Ana de Salazar, dándose la circunstancia de que los varones murieron sin descendencia $\mathrm{y}$, por ello, la beneficiaria fue doña Agustina [Liñán y] de Vera $^{88}$.

83. AHPrZ. Fondo Argillo, caja 2175/51 (leg. 70/51); caja 2135/43 (leg. 33/63). AHPZ. Francisco Abiego, $1644,26-X I$, ff. $2606 r-2608 v$ y ss.

84. Dejaba como tutores y ejecutores testamentarios a su mujer, a su padre don Jerónimo Pérez de Sayas, a su primo don Pedro Pablo [Fernández de Heredia y] Zapata, gobernador de Aragón, al doctor Juan Antonio Costas, lugarteniente del justicia de Aragón, don Jerónimo del Castillo, a doña Antonia de Sora, su cuñada, y a don Diego Arbas.

85. AHPrZ. Fondo Argillo, caja 2134/7 (leg. 31/7). De ello tenemos constancia puntual en 1654. AHPrH. Vicencio Santapau, 1654, 7-III, ff. 186v-188r.

86. Del que también disfrutó su nieto José. Así figuraba el 6 de mayo de 1662, cuando nombró procurador suyo a don Pedro Pablo Fernández de Heredia Zapata Ximénez y Urrea, conde de Aranda, domiciliado en Zaragoza. AHPrZ. Fondo Argillo, caja 2119/2 (leg. 18/8).

87. Juan Liñán y de Vera no tuvo descendencia de su matrimonio con doña María Ximénez de Embún. Juan, en sus relaciones extramatrimoniales, procreó una hija natural llamada Agustina de Vera. Esta última se casó con Juan de Baraiz y puso un significativo punto de partida a la rama materna del prócer don Vincencio Juan de Lastanosa. GÓMEZ ZORRAQUINO, J.I. Todo empezó bien. La familia del prócer Vincencio Juan de Lastanosa (siglos XVI-XVII), Zaragoza, Diputación de Zaragoza, 2004, pp. 78-91.

88. AHPrZ. Fondo Argillo, caja 2130/23 (leg. 28/47). 
El final de la intensa trayectoria vital de don Jerónimo Pérez de Sayas le llegó el 7 de mayo de 1657, en una vivienda de la parroquia oscense de la Seo -que confrontaba con casas de don Vincencio Juan de Lastanosa, con casas del heredero de micer Olcina,... $-{ }^{89}$. Con esta muerte desaparecía la persona que había dirigido durante más tiempo y en diferentes etapas la magistratura de justicia de las montañas de Aragón.

Don Jerónimo, según sus últimas voluntades de 5 de mayo de $1657^{90}$, deseaba que su cuerpo muerto fuese enterrado con el hábito de capuchino en la capilla del Sagrario de la iglesia del convento de Nuestra Señora del Carmen de Huesca ${ }^{91}$, donde se debían celebrar unas honras por su alma ocho días después de morir. El entierro debía ser con el cabildo de la Seo de Huesca y los canónigos debían portar velas blancas $^{92}$. Con la intención de salvar su alma hizo varias donaciones a instituciones de Huesca, Zaragoza y Catalayud ${ }^{93}$. Quería que se fundase una misa-aniversario en la Seo de Huesca a imagen y semejanza de las fundadas por el obispo oscense don Juan Moriz de Salazar (1616-1628) o el canónigo [doctor Martín Damasceno de] Cáncer, lo que debió de suponer que tal fundación se llevó a cabo en la capilla del Santo Cristo de los Milagros, donde descansaban las vísceras del obispo y el cuerpo del canónigo. Pedía que se entregasen 1.200 sueldos jaqueses al notario Vicente Santapau, una taza de plata sobredorada a «mi señora» (sic) doña Esperanza Gómez de Mendoza, 400 sueldos a Domingo Blusón «por lo bien que me ha servido», 200 sueldos a Juan Batista por sus servicios y 6.000 sueldos al conde Aranda (4.000 sueldos eran de la dote de la esposa del testador). Dejaba una herencia legítima, a quien le correspondiese, de 5 sueldos en bienes muebles y 5 sueldos en bienes inmuebles. Establecía que su nieta doña Teresa Pérez de Sayas y Sora -hija del difunto don Valero Pérez de Sayas y de doña Luisa de Sora- recibiese todo lo que fuese menester para su «colocación». Nombraba heredero universal a su nieto José de Sayas y Sora -hermano de doña Teresa-, aunque no podía serlo hasta que don Pedro Pablo Ximénez de Urrea Fernández de Heredia y

89. AHPrH. Vicencio Santapau, 1657, 7-V, ff. 384v y 387r. AHPrZ. Fondo Argillo, caja 2148/21 (leg. 43/21); caja 2135/44 (leg. 33/62). Actuó como testigo del óbito don Francisco de Lacabra, canónigo de la Seo de Huesca.

90. AHPrH. Vicencio Santapau, 1657, 5-V, f. 385r. (1r-10r). AHPrZ. Fondo Argillo, caja 2148/21 (leg. 43/21); caja 2135/44 (leg. 33/62)

91. La elección de esta sepultura estaba justificada porque el 2 de noviembre de 1641 don Pedro Pablo Fernández de Heredia, gobernador de Aragón, como señor de la capilla bajo la advocación de Nuestra Señora de la Concepción - realizada por los ejecutores y albaceas testamentarios de la difunta doña Petronila de Nueros, gobernadora viuda del difunto don Jerónimo [Fernández] de Heredia- en la iglesia del convento de Nuestra Señora del Carmen, admitió que en la sepultura que había en dicha capilla pudiesen enterrarse don Jerónimo Pérez de Sayas y los suyos. AHPrH. Vicencio Santapau, 1641, 2-XI, f. $968 \mathrm{v}$.

92. También quería que se celebrasen 1.650 misas en las iglesias oscenses y 200 misas en las iglesias de Calatayud.

93. A las instituciones oscenses les donaba las siguientes sumas: 1.000 sueldos a los padres capuchinos, 600 sueldos a las madres capuchinas, 500 sueldos a las madres carmelitas descalzas y 2.000 sueldos al Hopital de Nuestra Señora de la Esperanza. También entregaba 2.000 sueldos al Hopital de Nuestra Señora de Gracia de Zaragoza y 2.000 sueldos a la cofradía de la Misericordia de Calatayud. 
Zapata (sic), conde de Aranda, gobernador de Aragón, sobrino del testador, lo «digere y declarare ${ }^{94}$.

Tras la muerte de don Jerónimo, su nieto don José Pérez de Sayas y Sora, quien fue el último justicia de las montañas de Aragón, ejerció el cargo hasta que vio truncada su vida terrenal a los treinta y siete años en sus casas de Huesca el 18 de octubre de 1672 , y sin dejar testimonio de sus últimas voluntades ${ }^{95}$. Debió de morir sin tener descendencia directa ${ }^{96}$. Esta muerte supuso también el final de una magistratura que había cumplido unas finalidades muy específicas durante cerca de un siglo.

La ausencia de sucesores de don José propició que la familia Pérez de Sayas quedase representada por su hermana doña Teresa Pérez de Sayas y Sora, quien casó con don Bartolomé Pérez de Nueros en $1662^{97}$ y, gracias a ello, mantuvo encumbrada a la estirpe en la sociedad aragonesa. Lógicamente, también debemos pensar que don Bartolomé tuvo acceso a los favores reales gracias a que utilizó la «carta de presentación» de los méritos de sus antepasados y los de su esposa.

El infanzón doctor Bartolomé Pérez de Nueros -hijo de Jacinto Pérez de Nueros y Jacinta Navarro, hermano del infanzón Miguel José y de Jacinto, prior de la iglesia parroquial de San Lorenzo de Huesca $(1644-1654)^{98}$ y canónigo de la iglesia del Santo Sepulcro de Calatayud- ${ }^{99}$ estudió en las universidades de Zaragoza y Salamanca. El 19 de junio de 1643 consta que fue paje del gran maestre de la orden de San Juan en Malta $^{100}$. Ejerció la abogacía en Zaragoza entre 1658 y 1665, siendo también zalmedina de la ciudad durante un año. En 1660 fue designado lugarteniente del justicia de Aragón. El 24 de diciembre de 1660 fue nombrado del Consejo de Su Majestad en la sala de lo Criminal y, posteriormente, el 24 de junio de 1677, en la sala de lo Civil de la Real Audiencia aragonesa. Fue comisario insaculador en la villa de Ejea de los Caballeros (1666) y en la ciudad de Teruel (1674). Por privilegio real firmado en el Buen Retiro el 15 de junio de 1690 se convirtió en asesor del gobernador de Aragón, cargo que juró el 27 de junio de dicho año ante el justicia de Aragón y el 29 de dicho

94. Nombraba como ejecutores testamentarios al conde de Aranda, a don Francisco Rodrigo, abad de Montearagón, a don Francisco Lacabra Gómez y Mendoza, canónigo de la Catedral de Huesca, a don Martín de Sanjuán y Latrás y a don Jaime Juan Biota. También establecía que su heredero universal pudiese cancelar una comanda de 40.000 libras jaquesas cuando tuviese 25 años cumplidos.

95. AHPrZ. Fondo Argillo, caja 2169/11 (leg. 67/11).

96. AHPrZ. Fondo Argillo, caja 2130/4 (leg. 28/4); caja 2106/33 (leg. 6/20).

97. Los capítulos matrimoniales los firmaron el 10 de julio de 1662. AHPZ. Juan Gil Calvete, 1662, 10-VII, ff. 949v-996v; Juan Francisco Ibáñez de Aoiz, 1662, 10-VII, ff. 518v-621r. AHPrZ. Fondo Argillo, caja 2136/7 (leg. 33/61).

98. Jacinto se presentó el 4 de marzo de 1644 al priorato, vacante por el óbito de Bartolomé de Castro, último beneficiado. Renunció al cargo el 27 de agosto de 1654, sustituyéndole José Paulino Lastanosa, quien accedió al puesto el 26 de enero de 1655. A(rchivo) D(iocesano de) H(uesca). Procesos 3.1.285/7 (3239) y 3.1.648/11 (7815).

99. Este canónigo fue doctor en Cánones y síndico en las Cortes de Aragón de 1677-1678. GÓMEZ URIEL, M. Bibliotecas antigua y nueva..., op.cit., tomo II, p. 537.

100. De ello daba cuenta el gran maestre en una carta. AHPrZ. Fondo Argillo, caja 2169/35 (leg. 67/35). 
mes ante el virrey ${ }^{101}$. En 1694, ocupando dicho cargo, solicitó sin éxito la plaza de regente del Consejo Supremo de la Corona de Aragón, vacante por la muerte de don Martín Francisco Climente ${ }^{102}$. En 1700 también pidió, sin lograrlo, el ser nombrado justicia de Aragón, cargo que estaba libre por el óbito de don Pedro Valero Díaz ${ }^{103}$.

Este servicio de más de treinta y cinco años en la administración de justicia lo completó don Bartolomé -según sus palabras- con los treinta años que ocupó el oficio de auditor general de la gente de guerra y presidios de Aragón ${ }^{104}$. También fue el encargado del asiento de árboles del Pirineo y visitador del Real Patrimonio en Aragón ${ }^{105}$.

Buena parte de la vida profesional de don Bartolomé no se puede entender sin analizar su vida privada. Estamos seguros de que el apellido Pérez de Nueros -muy arraigado en la magistratura y en la vida pública aragonesa en general- vio reforzado su papel social con su casamiento con doña Teresa Pérez de Sayas -nieta, hija y hermana de tres justicias de las montañas de Aragón-, con quien se desposó el 9 de julio de 1662 en la parroquia zaragozana de la Magdalena ante don Jacinto Pérez de Nueros, canónigo del Santo Sepulcro de Calatayud, hermano del contrayente ${ }^{106}$.

Don Bartolomé, en las capitulaciones matrimoniales con doña Teresa, firmadas el 10 de julio de 1662, aportó propiedades inmobiliarias en diversas poblaciones de la Comunidad de Calatayud. Así, en Ibdes tenía los siguientes bienes: las casas principales con bodega, corrales y una huerta contigua de cuatro hanegas, tres portales de casas y un heredamiento de setenta hanegas. En Munébrega tenía nueve viñas, ocho yugadas de tierra y cuarenta libras jaquesas en diversos treudos sobre las heredades. En Belmonte poseía una casa con corrales, tres bodegas de vino, un huerto de tres hanegas, cincuenta hanegas de huerta, veinte yugadas en el monte de la población, un cerrado de ocho hanegas y dos viñas. En Calatayud disponía de unas casas en la plaza de Jorgal, otras casas y mesón, una era, una pieza de regadío de dos hanegas y otra pieza de la misma extensión. En Saviñán tenía un olivar. Don Bartolomé también llevó al matrimonio 2.166 sueldos jaqueses de renta con 31.000 sueldos de propiedad en tres censales cargados sobre el Concejo de Alagón, los concejos de Pedrola, Luna y

101. AHPrZ. Fondo Argillo, caja 2148/6 (leg. 43/6) y 2148/28 (leg. 43/28), caja 2143/23 (leg. 38/23). En ese momento el gobernador de Aragón era don Pedro Jerónimo de Urriés.

102. AHPrZ. Fondo Argillo, caja $2167 / 19$ (leg. 66/19), caja 2121/7 (leg. 19/17).

103. AHPrZ. Fondo Argillo, caja 2167/20 (leg. 66/20).

104. Relataba que prestó sus servicios en las jornadas siguientes: en 1661 en Alagón, en 1662 en Grañén, en 1664 en Graus, en 1669 salió a recibir a don Juan y lo sirvió desde Cataluña hasta Castilla, en 1675 fue a pedir servicio (a Huesca, Barbastro y otras ciudades), en 1677 salió a la frontera castellana para acompañar a Su Majestad hasta Zaragoza, en 1684 ajustó las diferencias de Castelserás y Alcañiz, en 1688 estuvo en la frontera valenciana con Aragón, y en 1691 consiguió un donativo de la ciudad y comunidad de Calatayud.

105. AHPrZ. Fondo Argillo, caja 2167/19 y 20 y caja 2121/7. De su papel de visitador del Real Patrimonio hay constancia por un despacho real de 29 de julio de 1690. AHPrZ. Fondo Argillo, caja 2130/11 (leg. 28/69).

106. ADZ. Quinque libri de la parroquia de la Magdalena de Zaragoza, libro de desposados, tomo $3^{\circ}$., f. 503 r. Don Jacinto fue autorizado por el vicario de dicha parroquia. 
Erla y sobre el estado de Aranda. El futuro contrayente también se debió de beneficiar después de contraer nupcias de las 200 libras jaquesas de renta anual que le donaba su hermano don Jacinto, en ese momento canónigo del Santo Sepulcro de Calatayud, cesión que debía durar mientras viviese el donante ${ }^{107}$.

Por su parte, doña Teresa aportó al matrimonio tres portales de casas en la entrada de la calle Armas de Zaragoza. Se daba la circunstancia de que la mitad de las citadas viviendas se las cedió su hermano don José, al igual que los siguientes bienes, que correspondían a la herencia de su abuelo don Jerónimo Pérez de Sayas ${ }^{108}$ : un censal de 3.000 sueldos de renta con 66.000 sueldos de propiedad cargado sobre el Concejo de Zaragoza, 1.000 libras jaquesas en trigo y 700 libras jaquesas. Doña Teresa recibió de su madre doña Luisa de Sora -para después de la muerte de esta última- las 6.000 libras jaquesas que eran parte de los 10.000 sueldos de renta que llevó al matrimonio, ya que la donante se reservaba 4.000 libras jaquesas para su libre disposición ${ }^{109}$.

Fruto de la unión carnal de don Bartolomé y doña Teresa nacieron tres hijos, llamados don Jacinto, doña Josefa Lamberta -bautizada el 20 de junio de 1665 en la parroquia zaragozana de la Magdalena ${ }^{110}$ y doña María Francisca Pérez de Nueros y Pérez de Sayas - desposada con don Francisco de Lacabra y Dara el 22 de febrero de 1688, en la parroquia zaragozana de la Magdalena- ${ }^{111}$.

Don Bartolomé Pérez de Nueros, estando sano, sintió la necesidad de redactar unas voluntades testamentarias el 18 de abril de $1693^{112}$, dándose la circunstancia de

107. Parte de dicha suma monetaria la sufragaba con las 110 libras jaquesas de la renta de la canonjía que tenía en la Catedral de Huesca.

108. Diez años después de la firma de los capítulos matrimoniales, más concretamente el 3 de noviembre de 1672, don Bartolomé Pérez de Nueros reconoció haber recibido de don Francisco de Lacabra, canónigo de la Catedral de Huesca - como ejecutor testamentario de don Jerónimo Pérez de Sayas- diversas piezas de plata. AHPrH. Vicencio Santapau, 1672, 3-XI, ff. 566r-568r.

109. Los capítulos matrimoniales se completaron, entre otros, con los siguientes acuerdos: don Bartolomé aseguraba a su futura esposa un excrex y aumento de dote de 3.000 libras jaquesas, con la obligación de que la beneficiaria dispusiese dicha cantidad en hijos del matrimonio. Si don Bartolomé llegaba a gozar de las 6.000 libras ofrecidas por doña Luisa de Sora, el excrex y aumento de dote debía ascender a 4.000 libras jaquesas. También se acordó que los bienes adquiridos a título lucrativo pertenecían al adquiriente. A la hora de disolverse el matrimonio, las joyas y vestidos eran para el sobreviviente, quien también tenía derecho de viudedad en los bienes muebles y sitios del premoriente. Un capítulo importante son los acuerdos que recogían la posibilidad - que se cumplió- de que doña Teresa se beneficiase del patrimonio de su único hermano don José [Pérez] de Sayas.

110. Se le bautizó con los nombres de Josefa Lamberta Antonia Fausta María Teresa Jacinta Luisa. ADZ. Quinque libri de la parroquia de la Magdalena de Zaragoza, libro de bautismos, tomo $4^{\circ}$., f. 4v.

111. ADZ. Quinque libri de la parroquia de la Magdalena de Zaragoza, libro de desposados, tomo $4^{\circ}$., f. 92 r. La capitulación matrimonial fue hecha el mismo día ante el notario zaragozano Francisco Salanova. Doña María Francisca testó el 17 de diciembre de 1701 ante el notario zaragozano Martín Ostabad.

112. AHPrZ. Fondo Argillo, caja 2147/56 (leg. 42/56). En el testamento reconocía su devoción hacia los santos José, Bartolomé y Teresa. Este parroquiano de la iglesia zaragozana de la Magdalena deseaba que su cuerpo muerto fuese enterrado en Calatayud, en la capilla del Santísimo Crucifijo del convento de San Pedro Mártir de la orden de Santo Domingo, donde estaba el enterratorio de la familia. Solicitaba la celebración de 1.500 misas por su alma y la fundación de un aniversario perpetuo en la citada iglesia 
que no fue la última vez y sus deseos perdieron validez legal. Además, el documento, firmado por el testador, no sabemos si fue registrado notarialmente.

Cuando el matrimonio estaba cerca de cumplir cuarenta años de convivencia, el doctor don Bartolomé falleció en su vivienda de la calle Mayor de Zaragoza el 30 ó 31 de octubre de $1701^{113}$. Las últimas voluntades del difunto fueron escrituradas conjuntamente con las de su esposa doña Teresa Pérez de Sayas el 28 de octubre de $1701^{114}$. En dicho documento se acordó lo siguiente: don Bartolomé deseaba que su cuerpo muerto fuese enterrado en el convento de San Pedro Mártir de Calatayud, de la orden de Santo Domingo, en la capilla del Santo Cristo, donde estaban sepultados sus padres y abuelos. Por su parte, doña Teresa quería descansar tras su vida terrenal en la capilla de San Juan Bautista del monasterio de Santa Engracia de Zaragoza, propiedad de sus abuelos maternos ${ }^{115}$. Dejaban una herencia legítima de 10 sueldos jaqueses de bienes y 10 sueldos de bienes inmuebles a cada uno de sus tres hijos, a su nieta Teresa Rosa y a quien le pudiese corresponder. Puntualmente daban a su hija Josefa Lamberta 200 onzas de plata y 150 libras jaquesas de renta anual durante su vida natural si no tenía hijos - pagaderas por el heredero universal, la mitad en dinero y la otra mitad en trigo-. Nombraban heredero universal a su hijo don Jacinto, con la condición de que debía disponer de la herencia en uno de sus dos hijos varones, "en aquel que quissiere elegir», y perpetuamente se debía nombrar a un sucesor varón, siendo llamadas las mujeres a la sucesión solamente cuando no hubiese varones. Para los desheredados, los testadores dejaban 6.000 libras jaquesas ${ }^{116}$.

de la Magdalena y otro aniversario en el convento bilbilitano donde quería ser enterrado. Señalaba «el grande y recíproco amor» que tenía el testador s su hermano Jacinto e indicaba a su esposa como «querida y amada muger». También enumeraba que don Agustín y don Cristóbal de Lacabra y Pérez de Nueros -hijos de don Francisco de Lacabra y Dara y de su hija María Francisca- y doña Teresa Rosa Pérez de Nueros -hija de su hijo Jacinto- eran sus nietos en ese momento. Instituía como heredero universal a su hijo don Jacinto Pérez de Nueros.

113. ADZ. Quinque libri de la parroquia de la Magdalena de Zaragoza, libro de difuntos, tomo $4^{\circ}$., f. 187 r. En este libro consta que el óbito se produjo el día 30. AHPZ. José Pérez de Oviedo, 1701, 31-X, ff. 889v891v. AHPrZ. Fondo Argillo, caja 2135/18 (leg. 33/54).

114. AHPZ. José Pérez de Oviedo, 1701, 28-X, ff. 893r-905r. AHPrZ. Fondo Argillo, caja 2135/18 (leg. 33/54).

115. Solicitaban la celebración de 2.000 misas por el alma de cada uno de los testadores, respectivamente. En la misma línea, se debía celebrar una misa rezada cada día durante el primer año después de sus respectivos óbitos. Por cada uno de los testadores se debían fundar dos aniversarios cantados perpetuamente, celebraderos el día que correspondía a la conmemoración de la muerte (don Bartolomé instituía uno en la iglesia parroquial de la Magdalena de Zaragoza y el otro en el convento de San Pedro Mártir de Calatayud. Por su parte, doña Teresa los fundaba en la citada iglesia de la Magdalena y en el convento zaragozano de Santa Engracia). Dejaban 350 reales de limosnas a los hospitales zaragozanos de Nuestra Señora de Gracia, Nuestra Señora de la Misericordia y de Niños y Niñas Huérfanos.

116. Nombraban como ejecutores testamentarios a doña Juana de Rocafull, condesa de Aranda y marquesa de La Vilueña, a su sobrino don José de Contamina, a su sobrino don Juan Miguel Pérez de Nueros y Femat, a sus hijos, a su sobrino don Antonio Pérez de Nueros y Abarca, a don Francisco Lacabra y Dara, al doctor Jaime Roc y a fray Jacinto Santarromana. 
Una vez que murió el doctor don Bartolomé Pérez de Nueros, el testigo familiar lo recogió su hijo el infanzón don Jacinto Pérez de Nueros y Pérez de Sayas, quien desde hacía tiempo había tomado innumerables responsabilidades. Tengamos en cuenta que don Jacinto había firmado los capítulos matrimoniales con su pariente lejana la bilbilitana doña Teresa Francisca Pérez de Nueros -hija del infanzón don Juan Miguel Pérez de Nueros y Femat y doña Isabel Caxol- ${ }^{117}$ el 19 de marzo de $1688^{118}$, y el mismo día se casaron en la iglesia parroquial de la Magdalena de Zaragoza ${ }^{119}$. Don Jacinto aportó al matrimonio diversos bienes inmuebles en las poblaciones de Terrer y Calatayud y varios treudos de trigo empeñados en 1.045 libras jaquesas -con carta de gracia reservada a don Baltasar Pérez de Nueros y Pueyo-. También los bienes de sus padres (la mitad del lugar de Pomer, las haciendas en Calatayud, Paracuellos de Jiloca, El Frasno, Ibdes y Saviñán), quienes se reservaban mientras viviesen el usufructo sobre dichos bienes y que el sobreviviente pudiese disponer libremente de 3.000 libras jaquesas. El contrayente también aportaba dos pensiones eclesiásticas de $200 \mathrm{y}$ 110 libras jaquesas de renta anual, pagaderas por el obispo de Albarracín y el arzobispado de Zaragoza, respectivamente ${ }^{120}$. Doña Teresa Francisca Pérez de Nueros llevó al matrimonio los siguientes bienes: 1.200 libras jaquesas de contado, varias fincas en Calatayud y Cadrete, 20.600 sueldos jaqueses de propiedad y 1.030 sueldos de renta en tres censales sobre el condado de Aranda, 1.000 escudos de un censal sobre el monasterio zaragozano de Santa Fe y 2.000 escudos del excrex y aumento de dote que le dio el padre a la madre de la contrayente cuando se casaron. Don Jacinto Pérez de Nueros firmaba y aseguraba a su futura esposa un excrex y aumento de dote de 2.000 libras jaquesas, con la condición de que dispusiese dicha cantidad monetaria en hijos del matrimonio.

117. Sus abuelos maternos eran don Juan Jaime Pérez de Nueros y la viuda doña Sabina Femat y Aznárez -esposa del difunto jurista doctor Juan Francisco de Falces y Lasarte-, quienes habían contraído matrimonio eclesiástico el 7 de febrero de 1646. Su tía carnal, llamada Sabina Pérez de Nueros, hermana de su padre, se casó en 1668 con don Nicolás de Olcina, miembro de una destacada familia de juristas. Cuando Juan Jaime otorgó testamento en Calatayud el 18 de abril de 1653 instituyó como heredero universal a su hijo don Juan Miguel, y su hija Sabina solamente tenía derecho a una dote de 5.000 libras jaquesas a la hora de contraer nupcias, como así ocurrió. GóMEZ ZORRAQUINO, J.I. «La endogamia profesional en la magistratura en Aragón (siglo XVII)», en prensa. AHPr.Z. Fondo Argillo, leg. 24/1.

El caballero oscense don Juan Miguel Pérez de Nueros y Femat escribió varios trabajos históricos -según Dormer-, tales como Escolios a la segunda parte de Patronado de Calatayud, de Miguel Martínez del Villar; la Historia de la ciudad de Calatayud; y continuó con el índice de los Anales de Zurita, trabajado por don Gaspar Ibáñez de Mendoza, marqués de Mondéjar. GómEz URIEL, M. Bibliotecas..., op.cit., tomo II, p. 537.

118. AHPZ. Braulio Villanueva, 1688, 19-III, ff. 607r-650v. AHPrZ. Fondo Argillo, caja $2136 / 9$ (leg. 33/97).

119. ADZ. Quinque libri de la parroquia de la Magdalena de Zaragoza, libro de desposados, tomo $4^{\circ}$., $\mathrm{f}$. $92 \mathrm{v}$.

120. Recibía estas pensiones por una gracia especial del papa Inocencio XI, de fecha 14 de febrero de 1688. AHPrZ. Fondo Argillo, legajo 58/39. 
Por el momento, no sabemos si sobrevivieron descendientes. Parece que doña Teresa Francisca, con su muerte, rompió la unión en fechas que desconocemos. El caballero hijodalgo don Jacinto Pérez de Nueros contrajo segundas nupcias con doña María Martina Solchaga (o Sorchaga) y Donamarsa, y fruto de dicha unión carnal sabemos que nacieron doña Teresa Rosa Pérez de Nueros - que contrajo matrimonio con don Joaquín de Vera, con quien procreó a Vicente y Joaquín-, doña María Vicenta Pérez de Nueros, bautizada el 15 de abril de 1711 en la iglesia parroquial de San Saturnino de Pamplona $^{121}$-que posteriormente casó con don Antonio Muñoz de Pamplona, de quien tuvo a Miguel, Manuel, Antonio, Francisca, Vicenta, Jacinta y María Josefa-, y doña Josefa Pérez de Nueros -que fue religiosa en el convento de las benitas de Calatayud-. Si atendemos a las últimas voluntades de don Bartolomé, a finales de octubre de 1701 vivían dos hijos varones de Jacinto, dándose la circunstancia de que desconocemos si eran fruto de sus primeras o segundas nupcias.

Don Jacinto tuvo una dilatada vida que se debió de prolongar hasta fechas cercanas al 18 de octubre de 1741, cuando firmó sus últimas voluntades en Zaragoza ante el notario José Domingo Asín, aunque estaba domiciliado en Calatayud, donde también vivían sus hijos ${ }^{122}$. En dicho día, estando enfermo, instituyó a sus hijas Vicenta y Teresa como herederas universales, «a medias y por iguales partes», dispuso que debían ajustarse a lo que dijese don Antonio Muñoz de Pamplona, su hijo (sic) político por la «segura confianza» que tenía en esta persona el testador.

Se da la circunstancia de que don Jacinto no siguió los pasos intelectuales de su padre y rompió con la presencia de la familia dentro de la administración de justicia. No estamos muy seguros - por las dificultades interpretativas que tenemos-de que además abandonase la permanente filiación familiar a la Monarquía, ya que don Jacinto debió de participar abiertamente en las disputas sucesorias que se dieron en España tras la muerte de Carlos II, tomando partido por la causa borbónica. De otra manera no se puede entender que don Jacinto Pérez de Nueros fuese acusado de los delitos de rebeldía, infidelidad y lesa majestad por la junta establecida por orden del archiduque Carlos de Austria. Entre el 21 de octubre de 1706 y el 18 de enero de 1707 fueron intervenidos sus bienes muebles y el patrimonio inmobiliario que tenía en Zaragoza, Calatayud, El Frasno, Ibdes, Saviñán, Terrer y Paracuellos de Jiloca ${ }^{123}$. El 24 de marzo de 1707 el proceso quedó visto para sentencia. Si hacemos caso del testimonio que

121. AHPrZ. Fondo Argillo, caja 2148/39 (leg. 43/39).

122. No hemos localizado la escritura de dicho notario en el Archivo Histórico de Protocolos de Zaragoza. AHPrZ. Fondo Argillo, caja 2135/20 (leg. 33/113).

123. AHPrZ. Fondo Argillo, caja 2148/10 (leg. 43/10). Ésta fue una cara de la moneda, ya que la otra la ocupó la Junta de Secuestros creada por orden de Felipe V en 1707 y posteriormente en 1711, encargada de secuestrar y gestionar los bienes de austracistas. Sobre esta última información se puede ver el trabajo de SÁNCHEZ GARCíA, S. «Noticias sobre austracistas aragoneses y el secuestro de sus bienes», Revista de Historia Moderna. Anales de la Universidad de Alicante, no. 25 (2007), pp. 257-301. Este autor -refiriendose a los reinos de Valencia y Cataluña- cita (en la nota 7) los trabajos de Jesús Pradells Nadal, Carmen Pérez Aparicio y Pedro Voltes Bou. 
ofreció Ignacio del Corral el 24 de febrero de 1708 -a instancia de don Jacinto Pérez de Nueros-, quien actuaba como procurador de la Real Chancillería de Zaragoza y secretario de los papeles y procesos llevados a cabo por el Tribunal de Secuestros durante la dominación del archiduque Carlos, el acusado don Jacinto fue juzgado con la propuesta de ser condenado a la pena ordinaria de «muerte de cuchillo», sus bienes confiscados y privado de todas las mercedes, honores, preeminencias y dignidades ${ }^{124}$.

Esta situación la superó el caballero hijodalgo don Jacinto porque se había apuntado al bando triunfador en la guerra de Sucesión y, además, fue compensado con el nombramiento de diputado perpetuo del Reino de Aragón ${ }^{125}$. Don Jacinto formó parte desde el 14 de diciembre de 1707 del primer ayuntamiento borbónico de la ciudad de Zaragoza como regidor por el estado de hidalgos y ciudadanos ${ }^{126}$, nombramiento real que era consecuencia de la fidelidad que había mostrado a la causa borbónica ${ }^{127}$. En este cargo municipal debió de estar nuestro protagonista hasta $1714^{128}$. De esta forma -en el contexto de nuestro análisis- nuevamente emergía la figura de un Pérez de Nueros cerca de la Monarquía, aunque en este caso la dinastía que reinaba era la borbónica.

Así pues, el casamiento de doña Teresa Pérez de Sayas y Sora con don Bartolomé Pérez de Nueros, la unión de don Jerónimo Pérez de Sayas con doña Violante Fernández de Heredia y Rueda, el enlace de don Juan Fernández de Heredia con doña Ana Luisa Zapata y Urrea y otros matrimonios ya citados nos están mostrando la configuración de un pequeño grupo de poder. Dicho grupo estaba muy cerca de la Monarquía y, por tal motivo, sus miembros se beneficiaban, entre otras cuestiones, de los más diversos oficios públicos de designación real. Se da la circunstancia -que no era casual- de que los componentes del grupo eran paisanos originarios de diversas poblaciones de la Comunidad de Calatayud -con alguna raíz en las poblaciones limítrofes de Castilla- y utilizaban esta relación y otras como el parentesco, la amistad,... para cerrar filas y ejercer todo su poder de influencia. Buena parte de las raíces de esta situación, posiblemente, debamos buscarlas en los comportamientos favorables a la Monarquía que tuvieron sus antepasados en los sucesos de la rebelión aragonesa de 1591 y en otros acontecimientos políticos anteriores y posteriores ${ }^{129}$. De igual forma, como ya hemos

124. AHPrZ. Fondo Argillo, caja 2148/32 (leg. 43/32).

125. AHPrZ. Fondo Argillo, caja 2148/39 (leg. 43/39).

126. PeIró Arroyo, A. Las Cortes Aragonesas de 1808. Pervivencias forales y revolución popular, Zaragoza, Cortes de Aragón, 1985, p. 26. MoRENO NIEVES, J.A. El poder local en Aragón durante el siglo XVIII. Los regidores aragoneses entre la Nueva Planta y la crisis del Antiguo Régimen, Zaragoza, Institución «Fernando el Católico», 2004, p. 86 (nota 260).

127. Esta fidelidad fue un elemento primordial en los nombramientos de los componentes de los primeros ayuntamientos aragoneses, algo que perduró hasta bien pasada la primera mitad del siglo XVIII. MORENO NiEVES, J.A. El poder local..., op.cit., pp. 136-137 y 201.

128. MoRenO NiEVES, J.A. El poder local..., op.cit., p. 562.

129. GASCÓN PÉREZ, J. La rebelión..., op.cit., pp. 1301-1304. No olvidemos, por ejemplo, que el caballero de la orden de Santiago don Juan Fernández de Heredia, gobernador de Aragón, contrajo nupcias con doña Luisa Zapata, hija de otro caballero de la misma orden, el bilbilitano don Manuel Zapata (c. 
analizado, la conexión de don Jacinto Pérez de Nueros con Felipe V partió del puntual apoyo que prestó este infanzón al monarca borbón en la guerra de Sucesión.

No queremos terminar este trabajo sin plantear que las coincidencias que encontramos entre el justicia de las montañas de Aragón y el justicia de Aragón nos permiten pensar que el «mito» del justicia de Aragón necesita una profunda revisión. Entramos en este territorio «vedado» porque ambos cargos eran de nombramiento real y estaban patrimonializados por familias -desde 1439 hasta 1591 el de justicia de Aragón-y por personas de clara filiación monárquica. A la vez, las dos magistraturas debían hacer respetar el ordenamiento foral aragonés, debían asegurar la autonomía de las jurisdicciones municipales y debían velar por la inviolabilidad de los derechos de los aragoneses libres, algo que se nos antoja imposible de conciliar. Esto, sin olvidar que la institución del Justicia de Aragón era el principal sostén del modelo de libertades aragonesas. Por ello, hay que revisar la historia política que se ha hecho a partir de las narraciones de los cronistas y de una serie de tópicos que no han sido contrastados ${ }^{130}$.

Aunque sin profundizar en el asunto -porque sería necesario conocer la práctica del ejercicio del poder de los justicias $\operatorname{citados}^{131}$, no es aventurado pensar que ese difícil equilibrio de intereses (los de la realeza, los regnícolas, los locales y los personales) se rompía a favor de los poderosos (la Monarquía, la alta nobleza y las élites sociales). Entre otras cuestiones, no debemos olvidar que la jurisdicción señorial tenía su propia vida sin interferencias externas. Tampoco debemos perder de vista que dichas élites sociales surtían de efectivos a los tribunales que debían aplicar las normas. Qué decir del poder del monarca y sus representantes cuando controlaban el acceso a los principales cargos, las más diversas prerrogativas y todo lo relacionado con el ascenso social. Por todo ello, cualquier análisis sobre la justicia -en singular o plural-y sus representantes debe considerar el territorio del día a día y la excepcionalidad. Todo lo demás es hacer proselitismo.

1556-1607). Se dio la circunstancia de que don Manuel Zapata tuvo una participación muy directa para ayudar a la Monarquía en su intento de capturar a Antonio Pérez cuando entró en Aragón.

130. Recientemente, sin entrar a valorar puntualmente las distintas interpretaciones y repartiendo parabienes, Jesús Morales Arrizabalaga ha resaltado - entre otras cuestiones- el significado del mito político de los Fueros de Sobrarbe, el papel de ideólogo-agitador del cronista Jerónimo de Blancas en su obra Comentarios de las cosas de Aragón, algunos errores y tópicos sobre la institución del Justicia Mayor (sic) y la historia política de Aragón tras «las actuaciones de 1591 y las reformas de 1592»,... MORALES Arrizabalaga, J. Fueros y Libertades del Reino de Aragón. De su formación medieval a la crisis preconstitucional (1076-1800), Zaragoza, Rolde de Estudios Aragoneses, 2007, pp. 64-97.

131. Hasta el momento no hemos localizado fondos documentales de los procesos llevados a cabo por el justicia de las montañas de Aragón. Además, creemos que, por las especiales circunstancias en que actuaba dicho magistrado, va a resultar complicado tener acceso a la citada documentación. 